\title{
BCL-2 family deregulation in colorectal cancer: potential for BH3 mimetics in therapy
}

\author{
Prashanthi Ramesh ${ }^{1,2} \cdot$ Jan Paul Medema ${ }^{1,2}$
}

Published online: 25 April 2020

(c) The Author(s) 2020

\begin{abstract}
Apoptosis is a form of programmed cell death that is essential for tissue homeostasis. De-regulation of the balance between proliferation and apoptosis contributes to tumor initiation. Particularly in the colon where apoptosis is a crucial process in intestinal turnover, inhibition of apoptosis facilitates transformation and tumor progression. The BCL-2 family of proteins are key regulators of apoptosis and have been implicated in colorectal cancer (CRC) initiation, progression and resistance to therapy. In this review we outline the current knowledge on the BCL-2 family-regulated intrinsic apoptosis pathway and mechanisms by which it is de-regulated in CRC. We further review BH3 mimetics as a therapeutic opportunity to target this pathway and evaluate their potential for CRC treatment.
\end{abstract}

Keywords Apoptosis $\cdot$ BCL-2 family $\cdot$ BH3 mimetics $\cdot$ Colorectal cancer

\section{Introduction}

Programmed cell death is an essential process regulating tissue homeostasis and stress response in many organisms. One of the most widely studied and well-characterized forms of programmed cell death is apoptosis, first described in the landmark study of Kerr et al. [1]. In their study they describe a unique morphology of dying cells which form membrane bound fragments that get phagocytosed by nearby cells. Further understanding of the pathway came from developmental studies conducted in the nematode Caenorhabditis elegans [2]. It is now well accepted that this process is tightly regulated by a set of proteins with specific interaction domains, most of which are conserved in mammals [2, 3]. In response to various signals, these proteins orchestrate a cascade of reactions that ultimately dictate the choice between life and death.

Jan Paul Medema

j.p.medema@amsterdamumc.nl

1 Laboratory for Experimental Oncology and Radiobiology, Center for Experimental and Molecular Medicine, Cancer Center Amsterdam, Amsterdam UMC, University of Amsterdam, Meibergdreef 9, 1105 AZ Amsterdam, The Netherlands

2 Oncode Institute, Meibergdreef 9, 1105 AZ Amsterdam, The Netherlands
While apoptosis occurs in normal tissue development and regeneration, it can also be activated in response to stress signals such as nutrient deprivation, reactive oxygen species and excessive mitogenic signaling usually associated with cancer initiation [4]. Such signals lead to the activation of one of the two main apoptotic pathways - the extrinsic and intrinsic pathways. The extrinsic pathway is regulated by so-called death receptors such as TNFR, FAS, DR3/WSL. Upon ligand binding these receptors activate signaling cascades that result in caspase activation, which is instrumental in the execution of apoptotic cell death. In this review we focus on the role of the BCL-2 family of proteins in cancer and hence on the intrinsic or mitochondrial pathway of apoptosis, which is regulated by this family [5].

Apoptosis is a key cell death mechanism that can counteract tumor formation and growth and for this reason, is often de-regulated in various cancers [6]. Increased proliferation resulting from oncogenic mutations is facilitated by genetic and epigenetic alterations in apoptotic pathways that ultimately allow uncontrolled tumor growth. Homeostasis in the colon is tightly regulated by a balance between proliferation and apoptosis. Disruption of this balance is an integral step in CRC development and progression. In addition, an increased apoptotic threshold is often observed in CRC tumors which contributes to therapy resistance [7]. In this review we describe how the members of the BCL-2 family regulate apoptosis and how they often get de-regulated 
to enable $\mathrm{CRC}$ progression and chemo-resistance. We further assess the potential of $\mathrm{BH} 3$ mimetics-small molecule antagonists of anti-apoptotic BCL-2 family members-as a therapeutic strategy for targeting this pathway and inducing apoptosis in CRC tumors.

\section{The intrinsic apoptosis pathway}

In the intrinsic apoptosis pathway, the BCL-2 family of proteins play a key role in determining the decision to undergo apoptosis. The first member of the BCL-2 family to be identified was the pro-survival B-cell lymphoma-2 ( $\mathrm{Bcl}-2)$ gene, which was found to be frequently amplified in lymphomas by an oncogenic translocation $[8,9]$. It was soon discovered that this protein was able to promote cancer cell survival by preventing apoptosis [10-12]. More than 15 members of this family have since been identified that can be segregated based on their apoptotic regulation as either pro- or antiapoptotic [13-17]. Here we describe how these members interact to regulate mitochondrial permeabilization.

\section{The pro- and anti- apoptotic BCL-2 proteins}

All members of the BCL-2 family of proteins show homology in one or more of the four BCL-2 homology (BH) domains and are categorized based on the number of homology domains they possess [18]. The anti-apoptotic members all have four BH-domains and include BCL-2, BCL-XL, MCL-1, BCL-W and A1/BFL-1. Of these, the BH1, BH2 and $\mathrm{BH} 3$ domains contribute to the formation of a hydrophobic pocket in their tertiary protein structure. The proapoptotic proteins can be divided into two sub-groups: the $\mathrm{BH} 3$-only proteins and the effector proteins. The $\mathrm{BH} 3$-only proteins, thus named as they only show homology to the BH3 domain of BCL-2 include BIM, BAD, BID, PUMA, NOXA, BMF, HRK, BIK and others. The effector proteins such as BAX and BAK possess three to four BH domains and are able to form macropores in the mitochondrial outer membrane. BOK is another multi-BH3 domain effector protein that has pro-apoptotic functions, which some studies suggest to be independent of BAX and BAK [19-21]. The physical interaction between anti- and pro-apoptotic proteins is a result of the binding of the $\mathrm{BH} 3$ domain of the pro-apoptotic proteins to the hydrophobic clefts of the anti-apoptotic proteins $[18,22,23]$.

\section{Regulation of mitochondrial permeabilization}

The vast majority of BAX and BAK molecules exist as inactive monomers (BAX) or homodimers (BAK) in an equilibrium between the cytosol and mitochondrial membrane [24-26]. BAX/BAK activation leads to the formation of pores that initiates the morphological changes associated with apoptosis [27]. Recent findings have shed light into detailed interaction models between these proteins that help provide new insights for targeting this pathway (Fig. 1) [5].

The mechanism by which $\mathrm{BH} 3$-only protein promote apoptosis is still a matter of intense debate. There is strong evidence for a "direct" model, which suggests that some $\mathrm{BH} 3$-only proteins can directly interact with BAX/BAK to induce conformational changes that leads to their activation [28-30]. These so called "activators" include BIM and BID and more recently PUMA and NOXA have shown to act as activators, although with lesser efficacy [31-34]. The other $\mathrm{BH} 3$ proteins such as BAD function as "sensitizers" in this model as they mainly interact with anti-apoptotic BCL-2 proteins to release the "activator" $\mathrm{BH} 3$-only proteins [31]. The anti-apoptotic BCL-2 proteins can inhibit apoptosis by two modes: either by directly engaging with and inhibiting activation of BAX/BAK or by sequestering activator BH3-only proteins, both of which prevent oligomerization of BAX and BAK (Fig. 1) [35]. Another "indirect" model proposes that the $\mathrm{BH} 3$-only proteins do not directly interact with BAX/BAK but instead act by binding to and neutralizing the anti-apoptotic proteins to release BAX/BAK and allow pore formation $[36,37]$. A recent study employed genome editing to delete all $\mathrm{BH} 3$-only proteins to generate an apoptosis resistant cell line. Interestingly, when MCL-1 and BCL-XL were inhibited in these cells the kinetics of

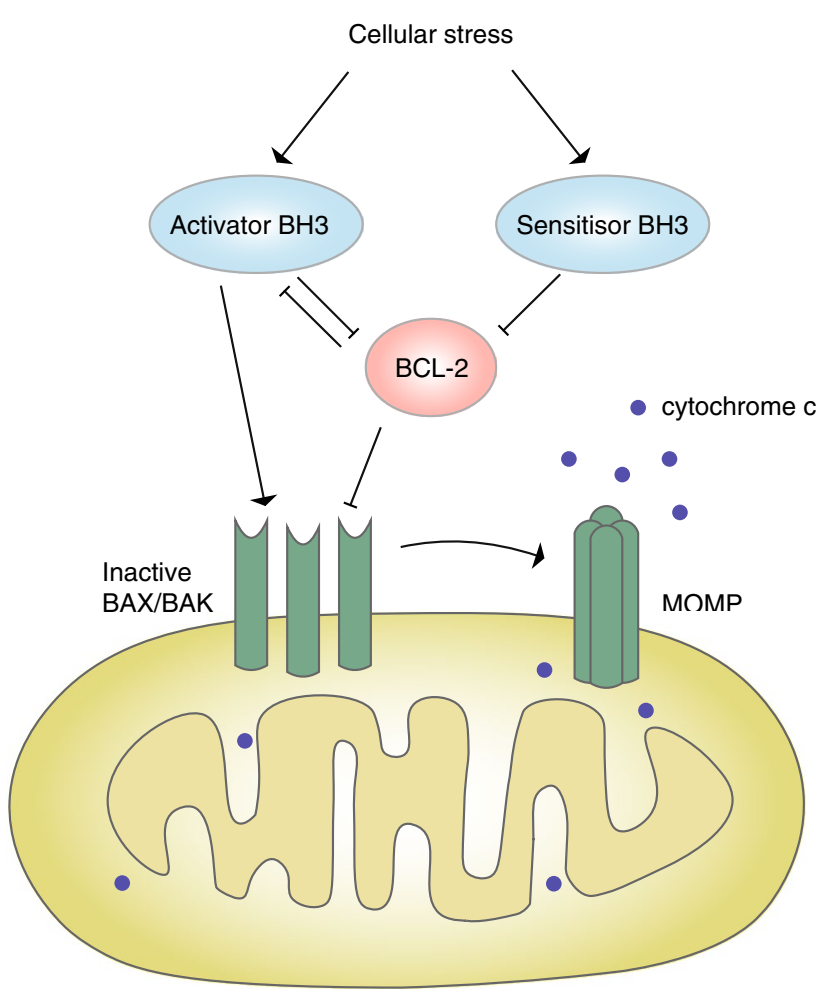

Fig. 1 BCL-2 family protein interactions regulate mitochondrial outer membrane permeabilization (MOMP) 
apoptosis was similar to the cells that did express all BH3only proteins. The authors therefore suggest that $\mathrm{BH} 3$-only proteins are not required for the direct activation of BAX and $\mathrm{BAK}$ and that they mainly function to repress BCL-XL and MCL-1 [37]. Even if they are not essential for BAX/ BAK activation, this does not exclude that $\mathrm{BH} 3$ activators can indeed facilitate pore formation through such direct interactions. Regardless of the prevailing model, when the balance is tipped in favor of pro-apoptotic molecules, BAX and BAK will multimerize to form pores in the outer mitochondrial membrane. Although less well studied, BOK was initially identified by its interactions with MCL-1 and is also suggested to have pore forming abilities [38, 39]. However, studies now propose its activation to be regulated by the endoplasmic reticulum-associated degradation pathway, independent of other BCL-2 protein interactions $[21,39$, 40].

Additional layers of complexity are added to these interaction models as the different members of the BCL-2 family show preferential binding patterns among each other. For instance, $\mathrm{BH} 3$-only proteins bind to pro-survival members with different affinities (Fig. 2). BH3-only proteins such as BIM, PUMA and tBID ("activators") can engage with all anti-apoptotic proteins whereas others are more limited in their interactions [41, 42]. BAD interacts with BCL-2, BCL$\mathrm{XL}$ and BCL-W, while HRK binds specifically to BCL-XL and NOXA shows preferential binding to MCL-1 and A1. Studies also show preferential interactions between activator BH3-only proteins and BAX and BAK. So while BID prefers to interact with BAK, BIM shows either no preference or preference for activation of BAX [30, 43]. An additional layer of complexity is introduced by specific interactions between anti-apoptotic proteins and effector proteins. For example, BAK is not inhibited by BCL-2 while MCL- 1 and $\mathrm{BCL}-\mathrm{XL}$ do restrain its activation [44]. Retrotranslocation of BAX and BAK away from the mitochondria into the cytosol is also regulated by the different pro-survival proteins. While BAX is retrotranslocated by BCL-2, BCL-XL and MCL-1, BAK retrotranslocation is only regulated by BCL$\mathrm{XL}$ and MCL-1 [26]. This retrotranslocation process prevents the activation of $\mathrm{BAX} / \mathrm{BAK}$ at the mitochondrial outer

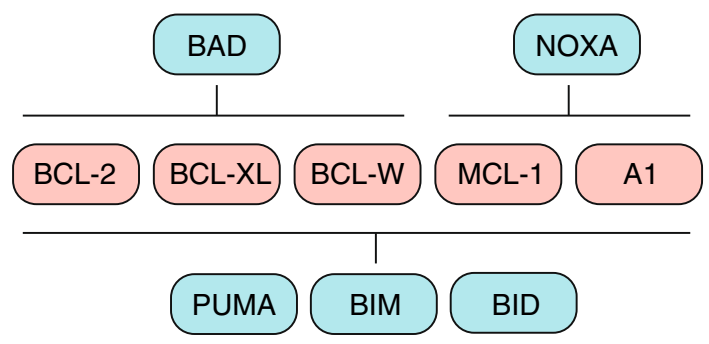

Fig. 2 BH3-only proteins have specific affinities for anti-apoptotic proteins membrane and thereby also prevents pore formation and mitochondrial outer membrane permeabilization (MOMP).

\section{Outcomes of MOMP}

MOMP is often considered to be the point of no return for apoptosis to occur [45]. Once the outer membrane is permeabilized by BAX/BAK pore formation, soluble proteins such as cytochrome $\mathrm{c}$ are released from the mitochondrial intermembrane space into the cytosol [46-48]. Here cytochrome c binds to APAF-1 to form the apoptosome, which activates caspase- 9 and ultimately leads to cleavage and activation of effector caspases such as caspase-3 or 7. MOMP also leads to the release of other proteins such as second mitochondria derived activator of caspase (SMAC) which releases caspase-3 from inhibitory proteins such as X-linked inhibitor of apoptosis (XIAP) [49]. The effector caspases are responsible for the cleavage of various proteins and eventual dismantling of the cell into apoptotic bodies. Despite being the executors of apoptosis, prevention of caspase activation does not always circumvent apoptosis. Permeabilized mitochondria can still lead to a cell's death in the absence of caspases due to mitochondrial distress, a form of death termed caspaseindependent cell death [50-52]. Interestingly, several studies report cell survival despite caspase activation [53-55]. When only a minority of mitochondria commit to MOMP, cells may prevent cell death and maintain their clonogenic potential [56]. In fact, the limited caspase activation resulting from this so called "minority MOMP" can induce caspase associated DNAse activity and thereby DNA damage. Cells that survive despite activation of the apoptotic pathway by such mechanisms may thus become genetically unstable and potentially tumorigenic [56-58].

\section{Mechanisms of apoptotic de-regulation}

De-regulated apoptosis is observed in most tumor types and is considered one of the hallmarks of cancer. Evasion of apoptosis allows tumor cells to bypass oncogene-induced cell death and can also promote sustained tumor growth, survival during metastatic spread and therapy resistance. De-regulation of the BCL-2 family not only occurs during tumorigenesis and outgrowth but is also observed as part of the tumor evolution that takes place in response to therapy [59-61]. The intrinsic pathway of apoptosis is often modified to tip the balance towards reduced apoptosis by altering one or both of the two main components of the pathway.

Not surprisingly, an increased expression of pro-survival BCL-2 proteins is found in several cancer types. This increase can be achieved by several mechanisms including chromosomal translocations [8], gene amplifications [62], increased transcription [63-65] and post-transcriptional and post-translational modifications (PTM) [66, 67]. 
Chromosomal gain mediated amplification of $\mathrm{Mcl}-\mathrm{l}$ and $\mathrm{Bcl}$ $x L$ were found to be the most frequent alterations across 26 tumor types, particularly in solid tumors [62]. Anti-apoptotic adaptation can also occur through PTMs that enhance the activity of pro-survival proteins $[68,69]$. Most tumors generally rely on the up-regulation of one or two anti-apoptotic proteins for resistance, which varies from tumor-to-tumor and even within the same tumor type [70-73]. Thus, most cancers present heterogeneous expression and dependence on anti-apoptotic proteins.

Another mechanism of altering the apoptotic threshold is to decrease the expression or modulate the activity of proapoptotic BH3-only proteins. Loss of BH3-only proteins is only mildly oncogenic on its own but can be tumorigenic in certain contexts such as co-occurrence with MYC activation [74]. Loss of P53 occurs in many cancers and leads to the downregulation of its transcriptional targets PUMA and NOXA $[75,76]$. Several studies document other tumorassociated changes in $\mathrm{BH} 3$-only proteins by various mechanisms including mutation, loss of heterozygosity or epigenetic silencing [77]. Reduced expression or activity of the BCL-2 family effector proteins is also a potent mechanism for apoptosis evasion in tumor cells. BAX somatic frameshift mutations are selected for in microsatellite instable gastric, colon and endometrial tumors [78]. Localization changes can also affect their apoptotic activity as observed in AML [79]. Studies have noted changes in their activity induced by phosphorylation and anti-cancer therapy that affect their pore forming abilities $[59,80]$. BOK deletions are quite frequently detected in a range of tumors [62]. However, BOK deficient mice show no overt phenotypic changes and cells derived from these mice are not hampered in apoptosis [81]. Several studies suggest that BOK exerts its anti-tumorigenic effects through non-apoptotic functions [82, 83]. On the other hand, a pro-tumorigenic role for BOK is reported in hepatocellular carcinoma where deletion of BOK is infrequent [84].

\section{De-regulation of the BCL-2 family in CRC}

Anti-apoptotic adaptation is a crucial step in CRC initiation and advancement. An accumulation of alterations that enable apoptosis evasion is observed as CRC progresses from adenoma-to-carcinoma stages. The increased apoptotic threshold hampers the efficacy of various chemotherapeutics and thus presents itself as a valuable target for CRC therapy. Several studies highlight modifications in the intrinsic apoptosis pathway at various stages of the disease. Here we review the role of the BCL-2 family in transformation of a healthy colon into adenomas and examine the pathway's deregulation as the disease progresses towards the carcinoma stage.

\section{Apoptosis in the normal colon}

Homeostasis in the colon is maintained by a balance between proliferation and apoptosis. The colonic epithelium consists of a single layer of epithelial cells that is organized to form invaginations called crypts [85]. Lgr5+ stem cells reside at the bottom of these crypts, which proliferate to give rise to intermediate transit amplifying cells [86]. Transit amplifying cells differentiate into various lineages as they move along the crypt towards the luminal face of the colon where they eventually get shed and die by apoptosis [87]. The entire colon gets renewed within $4-5$ days thus making apoptosis an active pathway in intestinal regeneration and maintenance. Two forms of apoptosis occur in the intestine-spontaneous apoptosis and damage-induced apoptosis. Spontaneous apoptosis occurs in general intestinal turnover whereas damage-induced apoptosis is elicited in response to stresses such as irradiation, chemotherapy and pathogens.

Several anti-apoptotic proteins and pro-apoptotic effectors are expressed in the colon and have important functions in both forms of apoptosis (Table 1). Studies on BCL-2 expression in the colon all conclude that it is mainly localized in the bottom of the crypt, where the stem cells reside [88]. On the other hand, BCL-XL and MCL-1 show more general expression in the normal intestine, not localized to a particular crypt compartment but specifically showing an apical staining pattern in cells $[89,90]$. BCL-W was hardly detectable in human normal tissue however a study in mice did show expression in the intestine [91, 92]. BAX and BAK expression in the crypts is more pronounced in the upper $2 / 3$ rd part than the bottom, in contrast to pro-survival BCL-2 $[90,93]$. These expression studies support the observed pattern of proliferation in the bottom of the crypt and apoptosis at the top.

Knockout (KO) mouse models of pro- and anti-apoptotic proteins provide insight into their role in spontaneous and damage-induced apoptosis in the colon. Homozygous BCL-2 null mice show increased spontaneous apoptosis compared to wild-type mice in the crypt bottom of the colon [88]. This however was not observed in the small intestine of BCL-2 KO mice, which show no overt phenotypic changes [88, 110]. An increase in damage-induced apoptosis upon irradiation and 5-FU treatment is also observed in the colonic stem cells of BCL-2 KO mice [111]. Intestinal specific BCL$\mathrm{XL}$ KO mice do not present with any changes to spontaneous apoptosis, thus maintaining colon integrity [104]. Similarly, knocking out BCL-W does not affect spontaneous intestinal apoptosis. However, these $\mathrm{KO}$ mice do display an important role for BCL-W in damage-induced apoptosis, particularly in the small intestine [91]. Both spontaneous and damageinduced apoptosis are unaffected by BAX KO, while the colon in BAK-null mice is significantly affected with crypt hyperplasia and reduced damage-induced apoptosis [111, 
Table 1 Expression alterations of BCL-2 family members in $\mathrm{CRC}$ progression from adenoma-to-carcinoma compared to healthy epithelium

\begin{tabular}{lllll}
\hline $\begin{array}{l}\text { BCL-2 family } \\
\text { protein }\end{array}$ & Normal & Adenoma & Adenocarcinoma & References \\
\hline BCL-2 & Expressed & Increase & Decrease & {$[94-99]$} \\
& & & Increase & {$[100,101]$} \\
& & Decrease & Decrease & {$[102]$} \\
& & No change & Increase & {$[103,104]$} \\
BCL-XL & Expressed & Increase & Increase & {$[90,102,104,105]$} \\
BCL-W & Not expressed & Not expressed & Increase & {$[92]$} \\
MCL-1 & Expressed & Increase & Decrease & {$[102]$} \\
& & Decrease & & {$[104]$} \\
BAX & Expressed & No change & No change & {$[90,102]$} \\
BAK & Expressed & Decrease & Decrease & {$[90,102]$} \\
PUMA & Expressed & - & Increase & {$[106]$} \\
NOXA & Expressed & - & No change & {$[107]$} \\
BID & Expressed & - & Increase & {$[108,109]$} \\
\hline
\end{tabular}

112]. The colon of BAK KO mice present with an increase in goblet cell numbers and a decrease in endocrine populations resulting from reduced basal apoptosis levels [112]. This suggests a unique role for BAK in regulating intestinal homeostasis that is not interchangeable with BAX.

\section{The BCL-2 family in intestinal transformation}

A progressive inhibition of apoptosis occurs during CRC progression [103]. This is particularly crucial during initiation where the tumor cell needs to overcome the apoptotic check in response to oncogenic signaling. Immunohistochemical (IHC) analysis of BCL-2 family protein expression in normal and adenoma tissues suggest that various members are de-regulated upon transformation (Table 1). IHC data indicate that colon adenomas have increased levels of anti-apoptotic protein BCL-XL while BCL-W is hardly detectable [92, 102, 104]. BCL-2 and MCL-1 stainings show inconsistent results in different studies. While several studies find an increase in BCL-2 protein levels in adenomas [94-101], there are also reports of either a decrease or no change in expression compared to normal tissue [102-104] (Table 1). However, the expression of BCL-2 specifically in the stem cells of the healthy colon has an important role in tumorigenesis [110]. Deletion of APC leads to adenoma formation in the mouse small intestine due to hyperactivation of the Wnt pathway. In stem cell-specific BCL-2 null mice, loss of APC gives rise to significantly fewer adenomas, thus indicating that BCL-2 is crucial for tumor initiation and survival [110]. Another study suggests an important role for BCL-XL in CRC development where intestinal epithelial cell-specific BCL-XL KO mice develop fewer tumors in an inflammation-driven tumor model [104]. Similarly, PUMA loss facilitates CRC progression as PUMA KO mice develop more adenomas in both the APC Min/+ and inflammation-driven tumor models [113]. As PUMA is driven largely by a p53 response, this suggests that oncogenic stress elicited by APC deletion drives a p53-dependent apoptotic response. IHC expression data of the effector proteins suggest that levels of pro-apoptotic protein BAX remain unchanged, while BAK is clearly decreased in adenomas (Table 1) [90, 102]. The observed downregulation of BAK could in part be due to oncogenic KRAS signaling. Ectopic re-expression of BAK in KRAS-transformed intestinal cells reduces their tumorigenicity [114]. More recently, a lesser known member of the BCL-2 family, namely BCL-G, was found to play a crucial role in colon tumorigenesis [115]. BCL-Gs (splice variant) only has the $\mathrm{BH} 3$ domain and has pro-apoptotic activity as it can bind to and inhibit BCL-XL [116]. Loss of BCL-G resulted in accelerated tumor formation in an inflammationdriven tumor model but not in the APC Min/+ mouse model [115]. Importantly, it is unclear whether this relates to its apoptotic functions as deletion affects the Mucin structure of the mucosal layer, indicating a non-apoptotic role for BCL-G in this context.

\section{The BCL-2 family in CRC carcinogenesis}

CRC develops in a step-wise manner with sequential accumulation of specific genetic mutations that dictate the progression from adenoma-to-carcinoma stages [117]. This progression is accompanied by several changes in the apoptotic threshold of the cancer cells with an overall inhibition of apoptosis [103]. Most members of the BCL-2 family show altered expression patterns in CRC tumors, which plays a role in cancer progression and therapy resistance.

Of the anti-apoptotic proteins, BCL-2 and MCL-1 expression is found to be decreased in CRC while BCL-XL and BCL-W show increased expression (Table 1). While BCL-2 plays a key role in adenoma formation, a progressive 
decrease in its expression during tumor progression indicates less of a role in CRC survival and resistance [90, 94-99, 110, 118]. The mechanism behind this decrease in expression has not been explored but studies suggest reciprocal regulation of BCL-2 and BCL-XL due to their inverse expression patterns [102]. Of all cancer types, $B c l-x L$ is amplified most often in cancers of the colon and a vast majority of CRCs present with BCL-XL overexpression [90, 102, 104, 105, 119]. This increased expression has been shown to be crucial for CRC survival and progression [90, 104, 119]. Colon cancer stem cells (CSCs) in particular are considered to be the chemo-refractory sub-population in primary CRC cultures and this resistance is mainly BCL-XL dependent [120]. Indeed, overexpression of BCL-XL in these cultures renders the differentiated population chemo-resistant [120]. De-regulation of anti-apoptotic MCL-1 also plays a crucial role in CRC chemo-resistance. While MCL-1 expression studies suggest decreased levels in CRC, it is important to note that its protein turnover rates are quite high with a half-life of approximately $30 \mathrm{~min}[121,122]$. Phosphorylation of MCL- 1 by GSK3 $\beta$ facilitates binding of FBW7, an E3 ubiquitin ligase which ubiquitylates and causes proteasomal degradation of MCL-1 [122, 123]. This degradation of MCL-1 is necessary for the efficacy of various targeted therapeutics against CRC cell lines [124]. Alterations in proteins regulating this degradation process often occur in CRC. Inactivating FBW7 mutations are found in CRC cell lines which promote MCL-1 stability and therefore, resistance to chemotherapy [123]. USP9X, a deubiquitinase enzyme that is reported to deubiquitinate and thus stabilizes MCL-1 protein levels, is also higher expressed in CRC cell lines [125].

In addition to the de-regulation of anti-apoptotic BCL-2 family members, several studies indicate altered expression and activity of the apoptosis effector proteins in CRC. BAK expression levels are decreased in colorectal tumors, but in most cases BAX levels appear to be unchanged [90, 102]. However, mutation analyses reveal the incidence of Bak mutations to be relatively low in CRC, but on the other hand, Bax frameshift mutations are quite frequently selected for in microsatellite instable tumors and this results in reduced apoptosis in BAX negative tumors [126-128]. The pro-apoptotic protein BAX interacting factor-1 (BIF-1) is found to be decreased in CRC tissues which might also result in reduced efficacy of BAX in CRC [129]. A recent study indicates a role for BOK in chemo-resistance in CRC as primary patient-derived organoids that are 5-FU resistant show decreased BOK expression compared to 5-FU sensitive organoids. This role is independent of its pro-apoptotic activity as the study shows BOK regulates uridine metabolism and thereby 5-FU chemo-conversion, thus a decrease in its expression promotes 5-FU resistance [130].

Of the pro-apoptotic BH3-only proteins, occasional mutations have been reported for $\mathrm{Bad}$, but no mutations were detected in Noxa, Puma and Bik in CRC tumors [106, 107, 131, 132]. 293T cells transfected with tumor-associated mutant BAD show decreased apoptosis induction and mutant BAD binds inefficiently to BCL-2 and BCL-XL [132]. Although mutations are infrequent, altered expression of BH3-only proteins is frequently observed in CRC. The promoter region of Hrk is found to be methylated in some CRC cases and treatment of cell lines with de-methylating agents re-introduces $H r k$ expression and sensitivity to chemotherapy [133]. An increased expression of PUMA and BID is detected in CRC, while NOXA levels remain unchanged (Table 1) [106-109]. This increase in proapoptotic proteins might be counter-intuitive for apoptosis evasion but most likely, such mechanisms are employed by a cell as a protective measure against transformation. Therefore, this increased expression could indicate the presence of compensatory mechanisms that enable tumor cells to override such selection pressures. PTMs that deregulate BH3-only proteins are also reported in CRC such as an increase in BAD phosphorylation, which attenuates BAD pro-apoptotic activity and facilitates tumorigenesis [106, 134, 135].

Considering the frequent alterations in the BCL-2 family that occur in CRC, various studies have assessed the potential of different members of the family as prognostic biomarkers for the disease [136]. However, due to the complex interactions of the various regulators of this pathway, none of the proteins on their own could reliably predict clinical response to therapy [136]. For this reason, a recent study employed a computational model that reflects the dynamic regulation of MOMP by the BCL-2 proteins to successfully identify high-risk CRC patients [137]. This highlights the importance of the various interactions among the BCL-2 family members that play a major role in determining tumor progression and therapy response.

\section{Targeting the BCL-2 family}

Cancer cells adapt to the various pressures of oncogenic transformation such as checkpoint evasion, metabolic stress and replicative damage by de-regulating the BCL-2 family and becoming more refractory to apoptosis. In order to handle these stress signals, the cancer cell is in a precarious position where it requires this apoptotic block to hold. This dependence on the BCL-2 family presents a therapeutic window of opportunity where pushing this block can specifically target cancer cells for apoptosis. Highly specific small molecule inhibitors called $\mathrm{BH} 3$ mimetics have therefore been developed to target anti-apoptotic BCL-2 proteins by mimicking the action of $\mathrm{BH} 3$-only proteins (Fig. 3). Here we review the reported efficacy of these inhibitors and examine their potential for CRC therapy. 


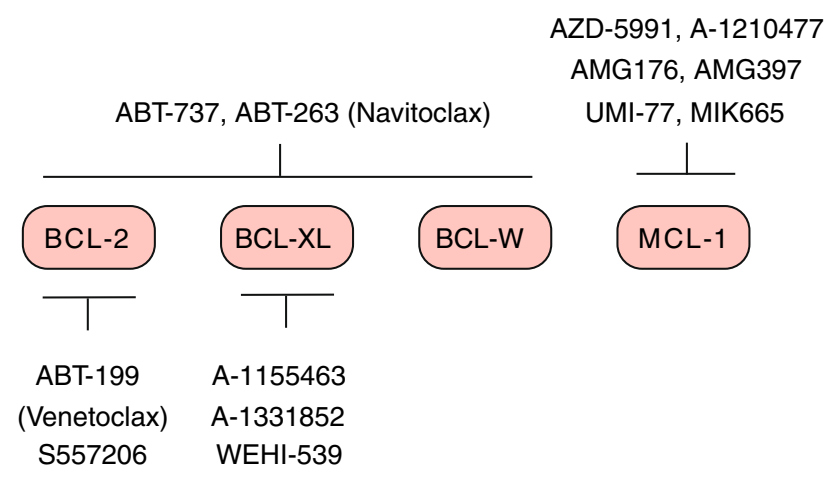

Fig. 3 An overview of selective BH3 mimetics designed to inhibit anti-apoptotic proteins

\section{BH3 mimetics: pushing the apoptotic block}

Early efforts to overcome the anti-apoptotic defense mechanism in cancer were mainly driven by screening libraries of natural products, which yielded several classes of compounds that can inhibit anti-apoptotic BCL-2 proteins [138]. Two of these, AT-101 and Obatoclax (GX15-070), have been tested in clinical trials for solid and hematological malignancies (see clinicaltrials.gov). Although these compounds can inhibit multiple anti-apoptotic BCL-2 members, they do not show sufficient clinical efficacy to warrant their approval $[138,139]$. Using structure-based design to selectively target anti-apoptotic proteins proved successful with the generation of ABT-737, the first BH3mimetic to be developed [140]. Designed using NMRbased screening, this compound mimics the binding pattern of BAD to inhibit the hydrophobic groove of BCL-2, BCL-XL and BCL-W. For clinical use, an orally bioavailable analog of ABT-737 was developed named ABT-263 or Navitoclax [141]. Notwithstanding the remarkable efficacy shown by this drug in pre-clinical studies [141-144], its use in the clinic is hampered by severe platelet toxicity [145]. Inhibition of BCL-XL in particular is found to be the cause of the observed thrombocytopenia, revealing its role in regulating platelet lifespan [146]. However, appropriate dosing strategies can help control the thrombocytopenia and indeed, several clinical trials testing the safety and efficacy of ABT-263 in a range of tumor types are ongoing (see clinicaltrials.gov) [139]. Another dual BCL-2 and BCL-XL inhibitor, AZD4320 shows potent tumor regression in vivo in hematological and solid malignancies [139]. This drug, re-formulated as a novel nanomedicine (AZD0466), is currently in a phase I clinical trial for both blood and solid tumors (NCT04214093). APG-1252 is another newly developed inhibitor of BCL-2 and BCL-XL that shows potent activity in vivo in small cell lung cancer models and triggers less platelet toxicity compared to Navitoclax [147]. The authors claim that this is because the drug on its own is poorly permeable but is converted to an active metabolite particularly in the tumor cells. This metabolite effectively reduces tumor growth while hardly being detected in the plasma, thereby avoiding toxicity [147]. Further study is needed and will come from phase I clinical trials, which are currently ongoing for lung cancer and other solid tumors in several countries (NCT03387332, NCT03080311, NCT04001777) [148].

To circumvent the observed platelet toxicity of inhibiting BCL-XL, it was hypothesized that specifically targeting BCL-2 could provide a wider therapeutic window with fewer toxicities. This led to the development of ABT-199 or Venetoclax, the first $\mathrm{BH} 3$ mimetic to receive FDA approval for relapsed/refractory chronic lymphocytic leukemia (R/R CLL) [149]. This landmark drug registration was followed by two more FDA approvals for Venetoclax in combination therapy for patients with R/R CLL and treatment naïve acute myeloid leukemia (AML) [139]. More than 200 clinical trials, particularly for hematological malignancies, have since been conducted or are ongoing (see clinicaltrials.gov) [150]. S55746 is another BCL-2 specific inhibitor which demonstrates significant efficacy against BCL-2 dependent tumors in vitro and in vivo and has been tested in two clinical trials (NCT02920697, NCT02603445) [139]. The results of the dose-escalation study have been recently released which show that the trial had to be terminated as the target active exposure of the drug in patients was not reached.

Studies of Venetoclax in solid tumors are limited with so far a trial in combination with tamoxifen for estrogen receptor positive breast cancers (ISRCTN98335443) and three others in a range of solid tumors (NCT03000257, NCT04029688, NCT03082209). These trials will test Venetoclax efficacy in combination with diverse compounds, which include the trail receptor agonist ABBV-621, MDM2 inhibitor Idasanutlin and anti-PD1 monoclonal antibody ABBV-181. Although there are promising indications for BCL-2 inhibition in solid tumors, anti-apoptotic adaptation is more closely associated with the overexpression of BCLXL [151]. Several BCL-XL inhibitors have been designed and the first specific inhibitor, WEHI-539, binds to BCL$\mathrm{XL}$ with high selectivity and affinity [152]. Since then, further efforts led to the design of A-1155463 and A-1331852, two far more potent inhibitors of which the latter is also orally bio-available $[153,154]$. Studies show promise for these inhibitors alone and in combination for treatment of solid tumors [154, 155]. A-1331852 enhances the efficacy of docetaxel in a range of solid tumors including breast cancer, NSCLC, and ovarian cancer both in vitro and in vivo [155]. In addition to this efficacy, BCL-XL inhibition does not result in neutropenia, which is a common toxicity of Venetoclax, shown to result from BCL-2 inhibition specifically [155]. While both these inhibitors induce platelet toxicity in vivo, this toxicity is reversible and therefore could 
be overcome by proper dosing strategies $[154,155]$. These promising inhibitors are yet to enter clinical trials.

In the wake of inhibitors targeting BCL-2 and BCL-XL, MCL-1 is emerging as an increasingly promising target given its role in malignant cell survival and resistance to various anti-cancer therapies. Several tumor types show heterogeneous dependence on MCL-1 including breast, lung, multiple myeloma (MM) and MYC-driven lymphomas [139]. Interestingly, there is evidence of MCL-1 expression levels increasing upon treatment with ABT-737 and this is implicated in resistance to other BH3 mimetics such as Navitoclax and Venetoclax, which do not inhibit MCL-1 $[156,157]$. MCL-1 is also involved in resistance to various chemotherapeutics, making it a promising target for combination and second-line treatment in resistant tumors [158, 159]. MCL-1 has proven far more difficult to target and only recently, successful specific inhibition has been achieved by BH3 mimetics such as A-1210477, UMI-77, S63845, AZD5991 and AMG176 [160]. A-1210477 shows in vitro efficacy against a range of cancer cell lines while UMI-77 is effective in vitro and in vivo against pancreatic and breast cancers $[161,162]$. AMG176 is the first MCL-1 inhibitor to enter a clinical trial for MM and AML (NCT02675452) [163]. It is also being tested in combination with Venetoclax for AML and non-Hodgkin's lymphoma (NHL) (NCT03797261). A similar Amgen MCL-1 inhibitor, AMG-397, is also being tested in the clinic for MM, AML and NHL (NCT03465540) [160]. However, trials for both these inhibitors have been recently suspended due to potential cardiac toxicity. Another MCL-1 specific inhibitor AZD-5991 shows significant antitumor activity in vivo with complete regression in mouse models of MM and AML, based on which a phase I clinical trial has been set up for patients with hematological malignancies (NCT03218683) [164]. A highly potent derivative of S63845 called S64315/MIK655 shows substantial in vivo activity against MM, AML and MYC-driven lymphomas and is also being tested in clinical trials for these malignancies as a monotherapy (NCT02992483, NCT02979366) and in combination with Venetoclax (NCT03672695) [165].

The approval of Venetoclax has heralded a new era of significant progress in therapeutic targeting of anti-apoptotic BCL-2 proteins (Fig. 3). A major challenge in the clinical application of these inhibitors is to predict the appropriate anti-apoptotic molecules to inhibit in a context-dependent and perhaps even a personalized manner. Dynamic BH3 profiling is one such technique that not only predicts the anti-apoptotic dependencies of a tumor, but also predicts response to various chemotherapeutics [18]. In this technique, control vs. drug-treated tumor cells are incubated with $\mathrm{BH} 3$ peptides that have specific anti-apoptotic binding partners (Fig. 2). Subsequent retention of cytochrome $\mathrm{c}$ is measured to assess the overall efficacy of the compound and the possible anti-apoptotic proteins that the tumor depends on. Such insight can not only predict treatment response in patients, but also greatly benefit the rationalized use of BH3-mimetics for treatment. Overall, these inhibitors not only show great promise for cancer therapy but also serve as invaluable tools for understanding the ever-changing antiapoptotic landscape of this disease.

\section{BH3 mimetics for CRC therapy}

While there are no CRC specific clinical trials testing the efficacy of $\mathrm{BH} 3$ mimetics, there is compelling evidence for the use of these inhibitors in CRC treatment. De-regulated expression of anti-apoptotic proteins is observed in all stages of CRC development and these changes can guide the use of BH3 mimetics for treatment. A recent study conducted in a panel of diverse cell lines finds that BCL-2 dependence directly correlates with BCL-2 expression levels, such that high expressers are more sensitive to ABT-199 treatment [166]. BCL-2 is expressed in crypt stem cells and plays a critical role in facilitating intestinal stem cell transformation and adenoma survival [110]. Treatment with ABT-199 while intestinal stem cells are undergoing APC deletion and hence transformation strongly impairs adenoma outgrowth, which suggests that BCL-2 is a potential target for CRC chemoprevention in patients with high risk conditions such as familial adenomatous polyposis [110]. However, BCL-2 expression is gradually lost as the disease progresses and most CRC cell lines are insensitive to ABT-199 [166]. Colon CSCs, which are particularly chemo-resistant, no longer express any BCL-2 and do not respond to ABT-199 treatment [120].

Considering the high levels of BCL-XL found in most CRC tissues, it has been a target of prime interest for CRC treatment [90, 104, 119]. Indeed the same colon CSCs that do not respond to BCL-2 inhibition are very sensitive to BCL-XL specific inhibitor WEHI-539, which impairs CSC clonogenicity and enhances the efficacy of chemotherapy [120]. The dual inhibitor ABT-737 also potently induces cell death in these CSCs while also showing efficacy on CRC ex vivo tissue and cell lines in combination with diverse chemotherapies [104, 120, 167, 168]. Several studies indicate that the efficacy of ABT-737, or its orally bioavailable counterpart ABT-263, in solid tumors is primarily due to the inhibition of BCL-XL [104, 120, 155]. The efficacy of BCL-XL inhibition is closely associated with MCL-1 activity, in particular predicted by NOXA expression which specifically inhibits MCL-1 [166]. Cells that express high level of NOXA either basally or induced by other therapies show increased sensitivity to BCL-XL inhibition by A-1155463 and ABT-737 [119, 169]. This suggests that concurrent treatment with MCL-1 inhibitors might potentiate the effect of BCL-XL inhibition in tumors that either present with high MCL-1 or low NOXA levels [170, 171]. In a CRC cell line HCT116, treatment with 
A-1155463 alone was sufficient to induce apoptosis, while MCL-1 inhibitor S63845 alone did not induce any apoptosis. However, combining the two compounds resulted in more pronounced apoptosis even in the absence of all BH3-only proteins, in a BAX dependent manner [171].

Taken together, these pre-clinical data suggest that BH3 mimetics hold great promise for CRC treatment. Early stage high risk adenomas that express BCL-2 might benefit from BCL-2 inhibition with ABT-199, thus preventing tumor progression. On the other hand treatment of more advanced carcinomas with BCL-XL specific inhibitors, perhaps in combination with MCL-1 inhibition might prove more effective. The main hindrance for the use BCL-XL inhibitors in clinical practice is the observed thrombocytopenia, as BCL-XL regulates platelet lifespan [146]. This can be managed by appropriate dosing strategies, particularly by using lower doses of the inhibitors in synergistic combinations with other chemotherapeutics [139]. Pre-clinical studies that test such possibilities would greatly aid the advancement of the use of $\mathrm{BH} 3$ mimetics in CRC therapy.

\section{Conclusions and future perspectives}

Recent findings have provided novel insights into the interactions of the BCL-2 family members that regulate the intrinsic pathway of apoptosis. Although the intricacies of this regulation are complex and still a matter of intense debate, it is clear that this family of proteins has an important role to play in homeostasis and tumorigenesis in the colon. De-regulation of the BCL-2 family occurs through various mechanisms and many CRC tumors show dependence on different anti-apoptotic proteins through different stages of the disease, making them a promising target for therapy. BH3 mimetics show potent induction of apoptosis in vitro and in vivo in various models. While BCL-2 inhibition can inhibit early adenoma outgrowth, CRC tumors respond well to BCL-XL specific inhibition, more so in combination with Mcl-1 inhibition. Implementing strategies to reduce the toxicities associated with these inhibitors and determining the appropriate $\mathrm{BH} 3$ mimetic to administer in a context-dependent and personalized manner (for example with dynamic BH3 profiling) could help untap the full potential of these novel inhibitors in CRC treatment.

Acknowledgements This work is supported by the Oncode Institute and Dutch Cancer Society (KWF) Grants UvA2015-7587 and 10150 (to J.P.M.). The authors would like to thank the lab of Giorgio Stassi, University of Palermo for providing the space and time to write this review.
Open Access This article is licensed under a Creative Commons Attribution 4.0 International License, which permits use, sharing, adaptation, distribution and reproduction in any medium or format, as long as you give appropriate credit to the original author(s) and the source, provide a link to the Creative Commons licence, and indicate if changes were made. The images or other third party material in this article are included in the article's Creative Commons licence, unless indicated otherwise in a credit line to the material. If material is not included in the article's Creative Commons licence and your intended use is not permitted by statutory regulation or exceeds the permitted use, you will need to obtain permission directly from the copyright holder. To view a copy of this licence, visit http://creativecommons.org/licenses/by/4.0/.

\section{References}

1. Kerr JF, Wyllie AH, Currie AR (1972) Apoptosis: a basic biological phenomenon with wide-ranging implications in tissue kinetics. Br J Cancer 26(4):239-257. https://doi.org/10.1038/ bjc. 1972.33

2. Horvitz HR (1999) Genetic control of programmed cell death in the nematode Caenorhabditis elegans. Cancer Res 59(7 Suppl):1701-1706

3. Opferman JT (2016) Attacking cancer's Achilles heel: antagonism of anti-apoptotic BCL-2 family members. FEBS J 283(14):2661-2675. https://doi.org/10.1111/febs.13472

4. Elmore S (2007) Apoptosis: a review of programmed cell death. Toxicol Pathol 35(4):495-516. https://doi.org/10.1080/01926 230701320337

5. Singh R, Letai A, Sarosiek K (2019) Regulation of apoptosis in health and disease: the balancing act of BCL-2 family proteins. Nat Rev Mol Cell Biol 20(3):175-193. https://doi.org/10.1038/ s41580-018-0089-8

6. Zhang L, Yu J (2013) Role of apoptosis in colon cancer biology, therapy, and prevention. Curr Colorectal Cancer Rep. https://doi. org/10.1007/s11888-013-0188-z

7. Ramachandran A, Madesh M, Balasubramanian KA (2000) Apoptosis in the intestinal epithelium: its relevance in normal and pathophysiological conditions. J Gastroenterol Hepatol 15(2):109-120. https://doi.org/10.1046/j.1440-1746.2000.02059 . $\mathrm{x}$

8. McDonnell TJ, Korsmeyer SJ (1991) Progression from lymphoid hyperplasia to high-grade malignant lymphoma in mice transgenic for the $t(14 ; 18)$. Nature 349(6306):254-256. https://doi. org/10.1038/349254a0

9. Vaux DL, Cory S, Adams JM (1988) Bcl-2 gene promotes haemopoietic cell survival and cooperates with c-myc to immortalize pre-B cells. Nature 335(6189):440-442. https://doi. org/10.1038/335440a0

10. Hockenbery D, Nunez G, Milliman C, Schreiber RD, Korsmeyer SJ (1990) Bcl-2 is an inner mitochondrial membrane protein that blocks programmed cell death. Nature 348(6299):334-336. https ://doi.org/10.1038/348334a0

11. Oltvai ZN, Milliman CL, Korsmeyer SJ (1993) Bcl-2 heterodimerizes in vivo with a conserved homolog, Bax, that accelerates programmed cell death. Cell74(4):609-619. https://doi. org/10.1016/0092-8674(93)90509-o

12. Strasser A, Harris AW, Bath ML, Cory S (1990) Novel primitive lymphoid tumours induced in transgenic mice by cooperation between myc and bcl-2. Nature 348(6299):331-333. https://doi. org/10.1038/348331a0

13. Boise LH, Gonzalez-Garcia M, Postema CE, Ding L, Lindsten T, Turka LA, Mao X, Nunez G, Thompson CB (1993) bcl-x, a bcl2-related gene that functions as a dominant regulator of apoptotic 
cell death. Cell 74(4):597-608. https://doi.org/10.1016/00928674(93)90508-n

14. Campbell KJ, Tait SWG (2018) Targeting BCL-2 regulated apoptosis in cancer. Open Biol. https://doi.org/10.1098/rsob.180002

15. Kozopas KM, Yang T, Buchan HL, Zhou P, Craig RW (1993) MCL1, a gene expressed in programmed myeloid cell differentiation, has sequence similarity to BCL2. Proc Natl Acad Sci USA 90(8):3516-3520. https://doi.org/10.1073/pnas.90.8.3516

16. Lin EY, Orlofsky A, Wang HG, Reed JC, Prystowsky MB (1996) A1, a Bcl-2 family member, prolongs cell survival and permits myeloid differentiation. Blood 87(3):983-992

17. O'Connor L, Strasser A, O'Reilly LA, Hausmann G, Adams JM, Cory S, Huang DC (1998) Bim: a novel member of the Bcl-2 family that promotes apoptosis. EMBO J 17(2):384-395. https ://doi.org/10.1093/emboj/17.2.384

18. Montero J, Letai A (2018) Why do BCL-2 inhibitors work and where should we use them in the clinic? Cell Death Differ 25(1):56-64. https://doi.org/10.1038/cdd.2017.183

19. Brem EA, Letai A (2016) BOK: oddball of the BCL-2 family. Trends Cell Biol 26(6):389-390. https://doi.org/10.1016/j. tcb.2016.04.007

20. Einsele-Scholz S, Malmsheimer S, Bertram K, Stehle D, Johanning J, Manz M, Daniel PT, Gillissen BF, Schulze-Osthoff K, Essmann F (2016) Bok is a genuine multi-BH-domain protein that triggers apoptosis in the absence of Bax and Bak. J Cell Sci 129(11):2213-2223. https://doi.org/10.1242/jcs.181727

21. Llambi F, Wang YM, Victor B, Yang M, Schneider DM, Gingras S, Parsons MJ, Zheng JH, Brown SA, Pelletier S, Moldoveanu T, Chen T, Green DR (2016) BOK Is a non-canonical BCL-2 family effector of apoptosis regulated by ER-associated degradation. Cell 165(2):421-433. https://doi.org/10.1016/j.cell.2016.02.026

22. Liu X, Dai S, Zhu Y, Marrack P, Kappler JW (2003) The structure of a Bcl-xL/Bim fragment complex: implications for Bim function. Immunity 19(3):341-352. https://doi.org/10.1016/ s1074-7613(03)00234-6

23. Sattler M, Liang H, Nettesheim D, Meadows RP, Harlan JE, Eberstadt M, Yoon HS, Shuker SB, Chang BS, Minn AJ, Thompson CB, Fesik SW (1997) Structure of Bcl-xL-Bak peptide complex: recognition between regulators of apoptosis. Science 275(5302):983-986. https://doi.org/10.1126/scien ce. 275.5302 .983

24. Edlich F, Banerjee S, Suzuki M, Cleland MM, Arnoult D, Wang C, Neutzner A, Tjandra N, Youle RJ (2011) Bcl-x(L) retrotranslocates Bax from the mitochondria into the cytosol. Cell 145(1):104-116. https://doi.org/10.1016/j.cell.2011.02.034

25. Schellenberg B, Wang P, Keeble JA, Rodriguez-Enriquez R, Walker S, Owens TW, Foster F, Tanianis-Hughes J, Brennan K, Streuli CH, Gilmore AP (2013) Bax exists in a dynamic equilibrium between the cytosol and mitochondria to control apoptotic priming. Mol Cell 49(5):959-971. https://doi.org/10.1016/j. molcel.2012.12.022

26. Todt F, Cakir Z, Reichenbach F, Emschermann F, Lauterwasser J, Kaiser A, Ichim G, Tait SW, Frank S, Langer HF, Edlich F (2015) Differential retrotranslocation of mitochondrial Bax and Bak. EMBO J 34(1):67-80. https://doi.org/10.15252/embj.20148 8806

27. Westphal D, Kluck RM, Dewson G (2014) Building blocks of the apoptotic pore: how Bax and Bak are activated and oligomerize during apoptosis. Cell Death Differ 21(2):196-205. https://doi. org/10.1038/cdd.2013.139

28. Letai A, Bassik MC, Walensky LD, Sorcinelli MD, Weiler S, Korsmeyer SJ (2002) Distinct BH3 domains either sensitize or activate mitochondrial apoptosis, serving as prototype cancer therapeutics. Cancer Cell 2(3):183-192. https://doi.org/10.1016/ s1535-6108(02)00127-7
29. Merino D, Giam M, Hughes PD, Siggs OM, Heger K, O'Reilly LA, Adams JM, Strasser A, Lee EF, Fairlie WD, Bouillet P (2009) The role of BH3-only protein Bim extends beyond inhibiting Bcl-2-like prosurvival proteins. J Cell Biol 186(3):355-362. https://doi.org/10.1083/jcb.200905153

30. Sarosiek KA, Chi X, Bachman JA, Sims JJ, Montero J, Patel L, Flanagan A, Andrews DW, Sorger P, Letai A (2013) BID preferentially activates BAK while BIM preferentially activates BAX, affecting chemotherapy response. Mol Cell 51(6):751-765. https ://doi.org/10.1016/j.molcel.2013.08.048

31. Chen HC, Kanai M, Inoue-Yamauchi A, Tu HC, Huang Y, Ren D, Kim H, Takeda S, Reyna DE, Chan PM, Ganesan YT, Liao CP, Gavathiotis E, Hsieh JJ, Cheng EH (2015) An interconnected hierarchical model of cell death regulation by the BCL-2 family. Nat Cell Biol 17(10):1270-1281. https://doi.org/10.1038/ncb32 36

32. Dai H, Smith A, Meng XW, Schneider PA, Pang YP, Kaufmann SH (2011) Transient binding of an activator BH3 domain to the Bak BH3-binding groove initiates Bak oligomerization. J Cell Biol 194(1):39-48. https://doi.org/10.1083/jcb.201102027

33. Du H, Wolf J, Schafer B, Moldoveanu T, Chipuk JE, Kuwana $\mathrm{T}$ (2011) BH3 domains other than Bim and Bid can directly activate Bax/Bak. J Biol Chem 286(1):491-501. https://doi. org/10.1074/jbc.M110.167148

34. Kim H, Rafiuddin-Shah M, Tu HC, Jeffers JR, Zambetti GP, Hsieh JJ, Cheng EH (2006) Hierarchical regulation of mitochondrion-dependent apoptosis by BCL-2 subfamilies. Nat Cell Biol 8(12):1348-1358. https://doi.org/10.1038/ncb1499

35. Llambi F, Moldoveanu T, Tait SW, Bouchier-Hayes L, Temirov J, McCormick LL, Dillon CP, Green DR (2011) A unified model of mammalian BCL-2 protein family interactions at the mitochondria. Mol Cell 44(4):517-531. https://doi.org/10.1016/j.molce 1.2011.10.001

36. Andreu-Fernandez V, Sancho M, Genoves A, Lucendo E, Todt F, Lauterwasser J, Funk K, Jahreis G, Perez-Paya E, Mingarro I, Edlich F, Orzaez M (2017) Bax transmembrane domain interacts with prosurvival Bcl-2 proteins in biological membranes. Proc Natl Acad Sci USA 114(2):310-315. https://doi.org/10.1073/ pnas. 1612322114

37. O’Neill KL, Huang K, Zhang J, Chen Y, Luo X (2016) Inactivation of prosurvival $\mathrm{Bcl}-2$ proteins activates Bax/Bak through the outer mitochondrial membrane. Genes Dev 30(8):973-988. https ://doi.org/10.1101/gad.276725.115

38. Hsu SY, Kaipia A, McGee E, Lomeli M, Hsueh AJ (1997) Bok is a pro-apoptotic Bcl-2 protein with restricted expression in reproductive tissues and heterodimerizes with selective anti-apoptotic Bcl-2 family members. Proc Natl Acad Sci USA 94(23):1240112406. https://doi.org/10.1073/pnas.94.23.12401

39. Zheng JH, Grace CR, Guibao CD, McNamara DE, Llambi F, Wang YM, Chen T, Moldoveanu T (2018) Intrinsic instability of BOK enables membrane permeabilization in apoptosis. Cell Rep 23(7):2083-2094. https://doi.org/10.1016/j.celrep.2018.04.060

40. Carpio MA, Michaud M, Zhou W, Fisher JK, Walensky LD, Katz SG (2015) BCL-2 family member BOK promotes apoptosis in response to endoplasmic reticulum stress. Proc Natl Acad Sci USA 112(23):7201-7206. https://doi.org/10.1073/pnas.14210 63112

41. Chen L, Willis SN, Wei A, Smith BJ, Fletcher JI, Hinds MG, Colman PM, Day CL, Adams JM, Huang DC (2005) Differential targeting of prosurvival $\mathrm{Bcl}-2$ proteins by their $\mathrm{BH} 3$-only ligands allows complementary apoptotic function. Mol Cell 17(3):393403. https://doi.org/10.1016/j.molcel.2004.12.030

42. Kuwana T, Bouchier-Hayes L, Chipuk JE, Bonzon C, Sullivan BA, Green DR, Newmeyer DD (2005) BH3 domains of BH3only proteins differentially regulate Bax-mediated mitochondrial 
membrane permeabilization both directly and indirectly. Mol Cell 17(4):525-535. https://doi.org/10.1016/j.molcel.2005.02.003

43. Lopez J, Bessou M, Riley JS, Giampazolias E, Todt F, Rochegue T, Oberst A, Green DR, Edlich F, Ichim G, Tait SW (2016) Mitopriming as a method to engineer Bcl-2 addiction. Nat Commun 7:10538. https://doi.org/10.1038/ncomms 10538

44. Willis SN, Chen L, Dewson G, Wei A, Naik E, Fletcher JI, Adams JM, Huang DC (2005) Proapoptotic Bak is sequestered by Mcl-1 and Bcl-xL, but not Bcl-2, until displaced by BH3-only proteins. Genes Dev 19(11):1294-1305. https://doi.org/10.1101/ gad. 1304105

45. Tait SW, Green DR (2013) Mitochondrial regulation of cell death. Cold Spring Harb Perspect Biol. https://doi.org/10.1101/ cshperspect.a008706

46. Bossy-Wetzel E, Newmeyer DD, Green DR (1998) Mitochondrial cytochrome $\mathrm{c}$ release in apoptosis occurs upstream of DEVDspecific caspase activation and independently of mitochondrial transmembrane depolarization. EMBO J 17(1):37-49. https:// doi.org/10.1093/emboj/17.1.37

47. Kluck RM, Bossy-Wetzel E, Green DR, Newmeyer DD (1997) The release of cytochrome $\mathrm{c}$ from mitochondria: a primary site for Bcl-2 regulation of apoptosis. Science 275(5303):1132-1136. https://doi.org/10.1126/science.275.5303.1132

48. Liu X, Kim CN, Yang J, Jemmerson R, Wang X (1996) Induction of apoptotic program in cell-free extracts: requirement for dATP and cytochrome c. Cell 86(1):147-157. https://doi.org/10.1016/ s0092-8674(00)80085-9

49. Maas C, Verbrugge I, de Vries E, Savich G, van de Kooij LW, Tait SW, Borst J (2010) Smac/DIABLO release from mitochondria and XIAP inhibition are essential to limit clonogenicity of Type I tumor cells after TRAIL receptor stimulation. Cell Death Differ 17(10):1613-1623. https://doi.org/10.1038/cdd.2010.39

50. Brunet CL, Gunby RH, Benson RS, Hickman JA, Watson AJ, Brady G (1998) Commitment to cell death measured by loss of clonogenicity is separable from the appearance of apoptotic markers. Cell Death Differ 5(1):107-115. https://doi. org/10.1038/sj.cdd.4400334

51. Lartigue L, Kushnareva Y, Seong Y, Lin H, Faustin B, Newmeyer DD (2009) Caspase-independent mitochondrial cell death results from loss of respiration, not cytotoxic protein release. Mol Biol Cell 20(23):4871-4884. https://doi.org/10.1091/mbc. E09-07-0649

52. Tait SW, Parsons MJ, Llambi F, Bouchier-Hayes L, Connell S, Munoz-Pinedo C, Green DR (2010) Resistance to caspaseindependent cell death requires persistence of intact mitochondria. Dev Cell 18(5):802-813. https://doi.org/10.1016/j.devce 1.2010.03.014

53. Ding AX, Sun G, Argaw YG, Wong JO, Easwaran S, Montell DJ (2016) CasExpress reveals widespread and diverse patterns of cell survival of caspase-3 activation during development in vivo. eLife. https://doi.org/10.7554/eLife.10936

54. Green DR (2019) The coming decade of cell death research: five riddles. Cell 177(5):1094-1107. https://doi.org/10.1016/j. cell.2019.04.024

55. Sun G, Guzman E, Balasanyan V, Conner CM, Wong K, Zhou HR, Kosik KS, Montell DJ (2017) A molecular signature for anastasis, recovery from the brink of apoptotic cell death. J Cell Biol 216(10):3355-3368. https://doi.org/10.1083/jcb.201706134

56. Ichim G, Lopez J, Ahmed SU, Muthalagu N, Giampazolias E, Delgado ME, Haller M, Riley JS, Mason SM, Athineos D, Parsons MJ, van de Kooij B, Bouchier-Hayes L, Chalmers AJ, Rooswinkel RW, Oberst A, Blyth K, Rehm M, Murphy DJ, Tait SWG (2015) Limited mitochondrial permeabilization causes DNA damage and genomic instability in the absence of cell death. Mol Cell 57(5):860-872. https://doi.org/10.1016/j.molce 1.2015.01.018
57. Giampazolias E, Zunino B, Dhayade S, Bock F, Cloix C, Cao K, Roca A, Lopez J, Ichim G, Proics E, Rubio-Patino C, Fort L, Yatim N, Woodham E, Orozco S, Taraborrelli L, Peltzer N, Lecis D, Machesky L, Walczak H, Albert ML, Milling S, Oberst A, Ricci JE, Ryan KM, Blyth K, Tait SWG (2017) Mitochondrial permeabilization engages NF-kappaB-dependent anti-tumour activity under caspase deficiency. Nat Cell Biol 19(9):11161129. https://doi.org/10.1038/ncb3596

58. Liu X, He Y, Li F, Huang Q, Kato TA, Hall RP, Li CY (2015) Caspase- 3 promotes genetic instability and carcinogenesis. Mol Cell 58(2):284-296. https://doi.org/10.1016/j.molce 1.2015 .03 .003

59. Goldsmith KC, GrossM, Peirce S, Luyindula D, Liu X, Vu A, Sliozberg M, Guo R, Zhao H, Reynolds CP, Hogarty MD (2012) Mitochondrial Bcl-2 family dynamics define therapy response and resistance in neuroblastoma. Cancer Res 72(10):2565-2577. https://doi.org/10.1158/0008-5472.Can-11-3603

60. Maji S, Panda S, Samal SK, Shriwas O, Rath R, Pellecchia M, Emdad L, Das SK, Fisher PB, Dash R (2018) Bcl-2 antiapoptotic family proteins and chemoresistance in cancer. Adv Cancer Res 137:37-75. https://doi.org/10.1016/bs.acr.2017.11.001

61. Winter PS, Sarosiek KA, Lin KH, Meggendorfer M, Schnittger S, Letai A, Wood KC (2014) RAS signaling promotes resistance to JAK inhibitors by suppressing BAD-mediated apoptosis. Sci Signal 7(357):ra122. https://doi.org/10.1126/scisignal.2005301

62. Beroukhim R, Mermel CH, Porter D, Wei G, Raychaudhuri S, Donovan J, Barretina J, Boehm JS, Dobson J, Urashima M, Mc Henry KT, Pinchback RM, Ligon AH, Cho YJ, Haery L, Greulich H, Reich M, Winckler W, Lawrence MS, Weir BA, Tanaka KE, Chiang DY, Bass AJ, Loo A, Hoffman C, Prensner J, Liefeld T, Gao Q, Yecies D, Signoretti S, Maher E, Kaye FJ, Sasaki H, Tepper JE, Fletcher JA, Tabernero J, Baselga J, Tsao MS, Demichelis F, Rubin MA, Janne PA, Daly MJ, Nucera C, Levine RL, Ebert BL, Gabriel S, Rustgi AK, Antonescu CR, Ladanyi M, Letai A, Garraway LA, Loda M, Beer DG, True LD, Okamoto A, Pomeroy SL, Singer S, Golub TR, Lander ES, Getz G, Sellers WR, Meyerson M (2010) The landscape of somatic copy-number alteration across human cancers. Nature 463(7283):899-905. https://doi.org/10.1038/nature08822

63. Allen JC, Talab F, Zuzel M, Lin K, Slupsky JR (2011) c-Abl regulates Mcl-1 gene expression in chronic lymphocytic leukemia cells. Blood 117(8):2414-2422. https://doi.org/10.1182/ blood-2010-08-301176

64. Catz SD, Johnson JL (2001) Transcriptional regulation of bcl-2 by nuclear factor kappa $\mathrm{B}$ and its significance in prostate cancer. Oncogene 20(50):7342-7351. https://doi.org/10.1038/ sj.onc. 1204926

65. Sevilla L, Zaldumbide A, Pognonec P, Boulukos KE (2001) Transcriptional regulation of the bcl-x gene encoding the antiapoptotic Bcl-xL protein by Ets, Rel/NFkappaB, STAT and AP1 transcription factor families. Histol Histopathol 16(2):595-601. https://doi.org/10.14670/hh-16.595

66. Cui J, Placzek WJ (2018) Post-transcriptional regulation of anti-apoptotic BCL2 family members. Int J Mol Sci. https://doi. org/10.3390/ijms19010308

67. Kampen KR, Sulima SO, Verbelen B, Girardi T, Vereecke S, Rinaldi G, Verbeeck J, Op de Beeck J, Uyttebroeck A, Meijerink JPP, Moorman AV, Harrison CJ, Spincemaille P, Cools J, Cassiman D, Fendt SM, Vermeersch P, De Keersmaecker K (2019) The ribosomal RPL10 R98S mutation drives IRES-dependent BCL-2 translation in T-ALL. Leukemia 33(2):319-332. https:// doi.org/10.1038/s41375-018-0176-z

68. Dai H, Ding H, Meng XW, Lee SH, Schneider PA, Kaufmann SH (2013) Contribution of Bcl-2 phosphorylation to Bak binding and drug resistance. Cancer Res 73(23):6998-7008. https://doi. org/10.1158/0008-5472.Can-13-0940 
69. Kutuk O, Letai A (2008) Regulation of Bcl-2 family proteins by posttranslational modifications. Curr Mol Med 8(2):102-118. https://doi.org/10.2174/156652408783769599

70. Chonghaile TN, Roderick JE, Glenfield C, Ryan J, Sallan SE, Silverman LB, Loh ML, Hunger SP, Wood B, DeAngelo DJ, Stone R, Harris M, Gutierrez A, Kelliher MA, Letai A (2014) Maturation stage of T-cell acute lymphoblastic leukemia determines BCL-2 versus BCL-XL dependence and sensitivity to ABT-199. Cancer Discov 4(9):1074-1087. https://doi.org/10.1158/21598290.Cd-14-0353

71. de Jong MRW, Langendonk M, Reitsma B, Nijland M, van den Berg A, Ammatuna E, Visser L, van Meerten T (2019) Heterogeneous pattern of dependence on anti-apoptotic BCL-2 family proteins upon $\mathrm{CHOP}$ treatment in diffuse large B-cell lymphoma. Int J Mol Sci. https://doi.org/10.3390/ijms20236036

72. Leverson JD, Sampath D, Souers AJ, Rosenberg SH, Fairbrother WJ, Amiot M, Konopleva M, Letai A (2017) Found in translation: how preclinical research is guiding the clinical development of the BCL2-selective inhibitor venetoclax. Cancer Discov 7(12):1376-1393. https://doi.org/10.1158/21598290.Cd-17-0797

73. Vogler M (2014) Targeting BCL2-proteins for the treatment of solid tumours. Adv Med 2014:943648. https://doi. org/10.1155/2014/943648

74. Egle A, Harris AW, Bouillet P, Cory S (2004) Bim is a suppressor of Myc-induced mouse B cell leukemia. Proc Natl Acad Sci USA 101(16):6164-6169. https://doi.org/10.1073/pnas.04014 71101

75. Nakano K, Vousden KH (2001) PUMA, a novel proapoptotic gene, is induced by p53. Mol Cell 7(3):683-694. https://doi. org/10.1016/s1097-2765(01)00214-3

76. Oda E, Ohki R, Murasawa H, Nemoto J, Shibue T, Yamashita T, Tokino T, Taniguchi T, Tanaka N (2000) Noxa, a BH3-only member of the Bcl-2 family and candidate mediator of p53induced apoptosis. Science 288(5468):1053-1058. https://doi. org/10.1126/science.288.5468.1053

77. Labi V, Erlacher M, Kiessling S, Villunger A (2006) BH3only proteins in cell death initiation, malignant disease and anticancer therapy. Cell Death Differ 13(8):1325-1338. https ://doi.org/10.1038/sj.cdd.4401940

78. Ouyang H, Furukawa T, Abe T, Kato Y, Horii A (1998) The BAX gene, the promoter of apoptosis, is mutated in genetically unstable cancers of the colorectum, stomach, and endometrium. Clin Cancer Res 4(4):1071-1074

79. Reichenbach F, Wiedenmann C, Schalk E, Becker D, Funk K, Scholz-Kreisel P, Todt F, Wolleschak D, Dohner K, Marquardt JU, Heidel F, Edlich F (2017) Mitochondrial BAX determines the predisposition to apoptosis in human AML. Clin Cancer Res 23(16):4805-4816. https://doi.org/10.1158/1078-0432. Ccr-16-1941

80. Kale J, Kutuk O, Brito GC, Andrews TS, Leber B, Letai A, Andrews DW (2018) Phosphorylation switches Bax from promoting to inhibiting apoptosis thereby increasing drug resistance. EMBO Rep. https://doi.org/10.15252/embr.201745235

81. Ke F, Voss A, Kerr JB, O'Reilly LA, Tai L, Echeverry N, Bouillet P, Strasser A, Kaufmann T (2012) BCL-2 family member BOK is widely expressed but its loss has only minimal impact in mice. Cell Death Differ 19(6):915-925. https:// doi.org/10.1038/cdd.2011.210

82. Chu J, Shi Z, Jiao Y, Han Z, Dou Q, Ye J, Cui X (2018) B-cell lymphoma 2 ovarian killer suppresses testicular cancer cell malignant behavior, but plays a role in platinum resistance. Anti-Cancer Drugs 29(9):839-846. https://doi.org/10.1097/ cad.0000000000000666

83. Moravcikova E, Krepela E, Donnenberg VS, Donnenberg AD, Benkova K, Rabachini T, Fernandez-Marrero Y, Bachmann
D, Kaufmann T (2017) BOK displays cell death-independent tumor suppressor activity in non-small-cell lung carcinoma. Int J Cancer 141(10):2050-2061. https://doi.org/10.1002/ijc.30906

84. Rabachini T, Fernandez-Marrero Y, Montani M, Loforese G, Sladky V, He Z, Bachmann D, Wicki S, Villunger A, Stroka D, Kaufmann T (2018) BOK promotes chemical-induced hepatocarcinogenesis in mice. Cell Death Differ 25(4):708-720. https ://doi.org/10.1038/s41418-017-0008-0

85. Blander JM (2018) On cell death in the intestinal epithelium and its impact on gut homeostasis. Curr Opin Gastroenterol 34(6):413-419. https://doi.org/10.1097/mog.0000000000 000481

86. Barker N, van Es JH, Kuipers J, Kujala P, van den Born M, Cozijnsen M, Haegebarth A, Korving J, Begthel H, Peters PJ, Clevers $\mathrm{H}$ (2007) Identification of stem cells in small intestine and colon by marker gene Lgr5. Nature 449(7165):1003-1007. https://doi. org/10.1038/nature06196

87. Blander JM (2016) Death in the intestinal epithelium-basic biology and implications for inflammatory bowel disease. FEBS J 283(14):2720-2730. https://doi.org/10.1111/ febs. 13771

88. Merritt AJ, Potten CS, Watson AJ, Loh DY, Nakayama K, Nakayama K, Hickman JA (1995) Differential expression of bcl-2 in intestinal epithelia. Correlation with attenuation of apoptosis in colonic crypts and the incidence of colonic neoplasia. J Cell Sci 108(Pt 6):2261-2271

89. Backus HH, Van Groeningen CJ, Vos W, Dukers DF, Bloemena E, Wouters D, Pinedo HM, Peters GJ (2002) Differential expression of cell cycle and apoptosis related proteins in colorectal mucosa, primary colon tumours, and liver metastases. J Clin Pathol 55(3):206-211. https://doi.org/10.1136/jcp.55.3.206

90. Maurer CA, Friess H, Buhler SS, Wahl BR, Graber H, Zimmermann A, Buchler MW (1998) Apoptosis inhibiting factor $\mathrm{Bcl}-\mathrm{xL}$ might be the crucial member of the $\mathrm{Bcl}-2$ gene family in colorectal cancer. Dig Dis Sci 43(12):2641-2648. https://doi. org/10.1023/a:1026695025990

91. Pritchard DM, Print C, O'Reilly L, Adams JM, Potten CS, Hickman JA (2000) Bcl-w is an important determinant of damageinduced apoptosis in epithelia of small and large intestine. Oncogene 19(34):3955-3959. https://doi.org/10.1038/sj.onc.1203729

92. Wilson JW, Nostro MC, Balzi M, Faraoni P, Cianchi F, Becciolini A, Potten CS (2000) Bcl-w expression in colorectal adenocarcinoma. Br J Cancer 82(1):178-185. https://doi.org/10.1054/ bjoc. 1999.0897

93. Liu LU, Holt PR, Krivosheyev V, Moss SF (1999) Human right and left colon differ in epithelial cell apoptosis and in expression of Bak, a pro-apoptotic Bcl-2 homologue. Gut 45(1):45-50. https ://doi.org/10.1136/gut.45.1.45

94. Flohil CC, Janssen PA, Bosman FT (1996) Expression of Bcl-2 protein in hyperplastic polyps, adenomas, and carcinomas of the colon. J Pathol 178(4):393-397

95. Hawkins N, Lees J, Hargrave R, O'Connor T, Meagher A, Ward $R$ (1997) Pathological and genetic correlates of apoptosis in the progression of colorectal neoplasia. Tumour Biol 18(3):146-156. https://doi.org/10.1159/000218025

96. Kaklamanis L, Savage A, Mortensen N, Tsiotos P, Doussis-Anagnostopoulou I, Biddolph S, Whitehouse R, Harris AL, Gatter KC (1996) Early expression of bcl-2 protein in the adenoma-carcinoma sequence of colorectal neoplasia. J Pathol 179(1):10-14

97. Kikuchi Y, Dinjens WN, Bosman FT (1997) Proliferation and apoptosis in proliferative lesions of the colon and rectum. Virchows Arch 431(2):111-117. https://doi.org/10.1007/s0042 80050076

98. Nakamura T, Sakai T, Nariya S (1995) Cell death in colorectal polyps as evaluated by in situ 3 '-tailing reaction and its 
relationship to BCL-2 expression. Pathol Int 45(10):721-728. https://doi.org/10.1111/j.1440-1827.1995.tb03388.x

99. Watson AJ, Merritt AJ, Jones LS, Askew JN, Anderson E, Becciolini A, Balzi M, Potten CS, Hickman JA (1996) Evidence of reciprocity of bcl-2 and p53 expression in human colorectal adenomas and carcinomas. Br J Cancer 73(8):889-895. https:// doi.org/10.1038/bjc. 1996.178

100. Bronner MP, Culin C, Reed JC, Furth EE (1995) The bcl-2 protooncogene and the gastrointestinal epithelial tumor progression model. Am J Pathol 146(1):20-26

101. Sinicrope FA, Ruan SB, Cleary KR, Stephens LC, Lee JJ, Levin B (1995) bcl-2 and p53 oncoprotein expression during colorectal tumorigenesis. Cancer Res 55(2):237-241

102. Krajewska M, Moss SF, Krajewski S, Song K, Holt PR, Reed JC (1996) Elevated expression of Bcl-X and reduced Bak in primary colorectal adenocarcinomas. Cancer Res 56(10):2422-2427

103. Bedi A, Pasricha PJ, Akhtar AJ, Barber JP, Bedi GC, Giardiello FM, Zehnbauer BA, Hamilton SR, Jones RJ (1995) Inhibition of apoptosis during development of colorectal cancer. Cancer Res 55(9):1811-1816

104. Scherr AL, Gdynia G, Salou M, Radhakrishnan P, Duglova K, Heller A, Keim S, Kautz N, Jassowicz A, Elssner C, He YW, Jaeger D, Heikenwalder M, Schneider M, Weber A, Roth W, Schulze-Bergkamen H, Koehler BC (2016) Bcl-xL is an oncogenic driver in colorectal cancer. Cell Death Dis 7(8):e2342. https://doi.org/10.1038/cddis.2016.233

105. Zhang YL, Pang LQ, Wu Y, Wang XY, Wang CQ, Fan Y (2008) Significance of Bcl-xL in human colon carcinoma. World $\mathrm{J}$ Gastroenterol 14(19):3069-3073. https://doi.org/10.3748/ wjg. 14.3069

106. Kim MR, Jeong EG, Chae B, Lee JW, Soung YH, Nam SW, Lee JY, Yoo NJ, Lee SH (2007) Pro-apoptotic PUMA and antiapoptotic phospho-BAD are highly expressed in colorectal carcinomas. Dig Dis Sci 52(10):2751-2756. https://doi.org/10.1007/ s10620-007-9799-z

107. Jansson AK, Emterling AM, Arbman G, Sun XF (2003) Noxa in colorectal cancer: a study on DNA, mRNA and protein expression. Oncogene 22(30):4675-4678. https://doi.org/10.1038/ sj.onc. 1206655

108. Krajewska M, Zapata JM, Meinhold-Heerlein I, Hedayat H, Monks A, Bettendorf H, Shabaik A, Bubendorf L, Kallioniemi OP, Kim H, Reifenberger G, Reed JC, Krajewski S (2002) Expression of Bcl-2 family member Bid in normal and malignant tissues. Neoplasia 4(2):129-140. https://doi.org/10.1038/ sj.neo.7900222

109. Sinicrope FA, Rego RL, Foster NR, Thibodeau SN, Alberts SR, Windschitl HE, Sargent DJ (2008) Proapoptotic Bad and Bid protein expression predict survival in stages II and III colon cancers. Clin Cancer Res 14(13):4128-4133. https://doi. org/10.1158/1078-0432.Ccr-07-5160

110. van der Heijden M, Zimberlin CD, Nicholson AM, Colak S, Kemp R, Meijer SL, Medema JP, Greten FR, Jansen M, Winton DJ, Vermeulen L (2016) Bcl-2 is a critical mediator of intestinal transformation. Nat Commun 7:10916. https://doi.org/10.1038/ ncomms 10916

111. Pritchard DM, Potten CS, Korsmeyer SJ, Roberts S, Hickman JA (1999) Damage-induced apoptosis in intestinal epithelia from bcl-2-null and bax-null mice: investigations of the mechanistic determinants of epithelial apoptosis in vivo. Oncogene 18(51):7287-7293. https://doi.org/10.1038/sj.onc.1203150

112. Duckworth CA, Pritchard DM (2009) Suppression of apoptosis, crypt hyperplasia, and altered differentiation in the colonic epithelia of bak-null mice. Gastroenterology 136(3):943-952. https ://doi.org/10.1053/j.gastro.2008.11.036

113. Qiu W, Carson-Walter EB, Kuan SF, Zhang L, Yu J (2009) PUMA suppresses intestinal tumorigenesis in mice. Cancer
Res 69(12):4999-5006. https://doi.org/10.1158/0008-5472. Can-09-0262

114. Rosen K, Rak J, Jin J, Kerbel RS, Newman MJ, Filmus J (1998) Downregulation of the pro-apoptotic protein Bak is required for the ras-induced transformation of intestinal epithelial cells. Curr Biol 8(24):1331-1334. https://doi.org/10.1016/s0960 $-9822(07) 00564-7$

115. Nguyen PM, Dagley LF, Preaudet A, Lam N, Giam M, Fung KY, Aizel K, van Duijneveldt G, Tan CW, Hirokawa Y, Yip HYK, Love CG, Poh AR, Cruz A, Burstroem C, Feltham R, Abdirahman SM, Meiselbach K, Low RRJ, Palmieri M, Ernst M, Webb AI, Burgess T, Sieber OM, Bouillet P, Putoczki TL (2020) Loss of Bcl-G, a Bcl-2 family member, augments the development of inflammation-associated colorectal cancer. Cell Death Differ 27(2):742-757. https://doi.org/10.1038/s41418-019-0383-9

116. Guo B, Godzik A, Reed JC (2001) Bcl-G, a novel pro-apoptotic member of the Bcl-2 family. J Biol Chem 276(4):2780-2785. https://doi.org/10.1074/jbc.M005889200

117. Fearon ER, Vogelstein B (1990) A genetic model for colorectal tumorigenesis. Cell 61(5):759-767. https://doi. org/10.1016/0092-8674(90)90186-i

118. Ofner D, Riehemann K, Maier H, Riedmann B, Nehoda H, Totsch M, Bocker W, Jasani B, Schmid KW (1995) Immunohistochemically detectable bcl-2 expression in colorectal carcinoma: correlation with tumour stage and patient survival. Br J Cancer 72(4):981-985. https://doi.org/10.1038/bjc.1995.446

119. Zhang H, Xue J, Hessler P, Tahir SK, Chen J, Jin S, Souers AJ, Leverson JD, Lam LT (2015) Genomic analysis and selective small molecule inhibition identifies BCL-X(L) as a critical survival factor in a subset of colorectal cancer. Mol Cancer 14:126. https://doi.org/10.1186/s12943-015-0397-y

120. Colak S, Zimberlin CD, Fessler E, Hogdal L, Prasetyanti PR, Grandela CM, Letai A, Medema JP (2014) Decreased mitochondrial priming determines chemoresistance of colon cancer stem cells. Cell Death Differ 21(7):1170-1177. https://doi. org/10.1038/cdd.2014.37

121. Adams KW, Cooper GM (2007) Rapid turnover of mcl-1 couples translation to cell survival and apoptosis. J Biol Chem 282(9):6192-6200. https://doi.org/10.1074/jbc.M610643200

122. Maurer U, Charvet C, Wagman AS, Dejardin E, Green DR (2006) Glycogen synthase kinase-3 regulates mitochondrial outer membrane permeabilization and apoptosis by destabilization of MCL1. Mol Cell 21(6):749-760. https://doi.org/10.1016/j.molce 1.2006.02.009

123. Tong J, Tan S, Zou F, Yu J, Zhang L (2017) FBW7 mutations mediate resistance of colorectal cancer to targeted therapies by blocking Mcl-1 degradation. Oncogene 36(6):787-796. https:// doi.org/10.1038/onc.2016.247

124. Tong J, Wang P, Tan S, Chen D, Nikolovska-Coleska Z, Zou F, Yu J, Zhang L (2017) Mcl-1 degradation is required for targeted therapeutics to eradicate colon cancer cells. Cancer Res 77(9):2512-2521. https://doi.org/10.1158/0008-5472. Can-16-3242

125. Schwickart M, Huang X, Lill JR, Liu J, Ferrando R, French DM, Maecker H, O'Rourke K, Bazan F, Eastham-Anderson J, Yue P, Dornan D, Huang DC, Dixit VM (2010) Deubiquitinase USP9X stabilizes MCL1 and promotes tumour cell survival. Nature 463(7277):103-107. https://doi.org/10.1038/nature08646

126. Miquel C, Borrini F, Grandjouan S, Auperin A, Viguier J, Velasco V, Duvillard P, Praz F, Sabourin JC (2005) Role of bax mutations in apoptosis in colorectal cancers with microsatellite instability. Am J Clin Pathol 123(4):562-570. https://doi. org/10.1309/jq2x-3rv3-18f9-tgyw

127. Rampino N, Yamamoto H, Ionov Y, Li Y, Sawai H, Reed JC, Perucho M (1997) Somatic frameshift mutations in the BAX gene in colon cancers of the microsatellite mutator phenotype. 
Science 275(5302):967-969. https://doi.org/10.1126/scien ce.275.5302.967

128. Sakamoto I, Yamada T, Ohwada S, Koyama T, Nakano T, Okabe T, Hamada K, Kawate S, Takeyoshi I, Iino Y, Morishita Y (2004) Mutational analysis of the BAK gene in 192 advanced gastric and colorectal cancers. Int J Mol Med 13(1):53-55

129. Coppola D, Khalil F, Eschrich SA, Boulware D, Yeatman T, Wang HG (2008) Down-regulation of Bax-interacting factor-1 in colorectal adenocarcinoma. Cancer 113(10):2665-2670. https ://doi.org/10.1002/cncr.23892

130. Srivastava R, Cao Z, Nedeva C, Naim S, Bachmann D, Rabachini T, Gangoda L, Shahi S, Glab J, Menassa J, Osellame L, Nelson T, Fernandez-Marrero Y, Brown F, Wei A, Ke F, O'Reilly L, Doerflinger M, Allison C, Kueh A, Ramsay R, Smith BJ, Mathivanan S, Kaufmann T, Puthalakath H (2019) BCL-2 family protein BOK is a positive regulator of uridine metabolism in mammals. Proc Natl Acad Sci USA 116(31):15469-15474. https:// doi.org/10.1073/pnas.1904523116

131. Abdel-Rahman W, Arends M, Morris R, Ramadan M, Wyllie A (1999) Death pathway genes Fas (Apo-1/CD95) and Bik (Nbk) show no mutations in colorectal carcinomas. Cell Death Differ 6(5):387-388. https://doi.org/10.1038/sj.cdd.4400511

132. Lee JW, Soung YH, Kim SY, Nam SW, Kim CJ, Cho YG, Lee JH, Kim HS, Park WS, Kim SH, Lee JY, Yoo NJ, Lee SH (2004) Inactivating mutations of proapoptotic Bad gene in human colon cancers. Carcinogenesis 25(8):1371-1376. https://doi. org/10.1093/carcin/bgh 145

133. Obata T, Toyota M, Satoh A, Sasaki Y, Ogi K, Akino K, Suzuki H, Murai M, Kikuchi T, Mita H, Itoh F, Issa JP, Tokino T, Imai K (2003) Identification of HRK as a target of epigenetic inactivation in colorectal and gastric cancer. Clin Cancer Res 9(17):6410-6418

134. Khor TO, Gul YA, Ithnin H, Seow HF (2004) Positive correlation between overexpression of phospho-BAD with phosphorylated Akt at serine 473 but not threonine 308 in colorectal carcinoma. Cancer Lett 210(2):139-150. https://doi.org/10.1016/j.canle t.2004.01.017

135. Stickles XB, Marchion DC, Bicaku E, Al Sawah E, Abbasi F, Xiong Y, Bou Zgheib N, Boac BM, Orr BC, Judson PL, Berry A, Hakam A, Wenham RM, Apte SM, Berglund AE, Lancaster JM (2015) BAD-mediated apoptotic pathway is associated with human cancer development. Int J Mol Med 35(4):1081-1087. https://doi.org/10.3892/ijmm.2015.2091

136. Hector S, Prehn JH (2009) Apoptosis signaling proteins as prognostic biomarkers in colorectal cancer: a review. Biochim Biophys Acta 1795(2):117-129. https://doi.org/10.1016/j.bbcan .2008.12.002

137. Lindner AU, Salvucci M, Morgan C, Monsefi N, Resler AJ, Cremona M, Curry S, Toomey S, O’Byrne R, Bacon O, Stuhler M, Flanagan L, Wilson R, Johnston PG, Salto-Tellez M, CamilleriBroet S, McNamara DA, Kay EW, Hennessy BT, Laurent-Puig P, Van Schaeybroeck S, Prehn JHM (2017) BCL-2 system analysis identifies high-risk colorectal cancer patients. Gut 66(12):21412148. https://doi.org/10.1136/gutjnl-2016-312287

138. Lessene G, Czabotar PE, Colman PM (2008) BCL-2 family antagonists for cancer therapy. Nat Rev Drug Discov 7(12):9891000. https://doi.org/10.1038/nrd2658

139. Ashkenazi A, Fairbrother WJ, Leverson JD, Souers AJ (2017) From basic apoptosis discoveries to advanced selective BCL-2 family inhibitors. Nat Rev Drug Discov 16(4):273-284. https:// doi.org/10.1038/nrd.2016.253

140. Oltersdorf T, Elmore SW, Shoemaker AR, Armstrong RC, Augeri DJ, Belli BA, Bruncko M, Deckwerth TL, Dinges J, Hajduk PJ, Joseph MK, Kitada S, Korsmeyer SJ, Kunzer AR, Letai A, Li C, Mitten MJ, Nettesheim DG, Ng S, Nimmer PM, O'Connor JM, Oleksijew A, Petros AM, Reed JC, Shen W, Tahir SK, Thompson
CB, Tomaselli KJ, Wang B, Wendt MD, Zhang H, Fesik SW, Rosenberg SH (2005) An inhibitor of Bcl-2 family proteins induces regression of solid tumours. Nature 435(7042):677-681. https://doi.org/10.1038/nature03579

141. Tse C, Shoemaker AR, Adickes J, Anderson MG, Chen J, Jin S, Johnson EF, Marsh KC, Mitten MJ, Nimmer P, Roberts L, Tahir SK, Xiao Y, Yang X, Zhang H, Fesik S, Rosenberg SH, Elmore SW (2008) ABT-263: a potent and orally bioavailable Bcl-2 family inhibitor. Cancer Res 68(9):3421-3428. https://doi. org/10.1158/0008-5472.Can-07-5836

142. Ackler S, Mitten MJ, Foster K, Oleksijew A, Refici M, Tahir SK, Xiao Y, Tse C, Frost DJ, Fesik SW, Rosenberg SH, Elmore SW, Shoemaker AR (2010) The Bcl-2 inhibitor ABT-263 enhances the response of multiple chemotherapeutic regimens in hematologic tumors in vivo. Cancer Chemother Pharmacol 66(5):869880. https://doi.org/10.1007/s00280-009-1232-1

143. Chen J, Jin S, Abraham V, Huang X, Liu B, Mitten MJ, Nimmer P, Lin X, Smith M, Shen Y, Shoemaker AR, Tahir SK, Zhang H, Ackler SL, Rosenberg SH, Maecker H, Sampath D, Leverson JD, Tse C, Elmore SW (2011) The Bcl-2/Bcl-X(L)/Bcl-w inhibitor, navitoclax, enhances the activity of chemotherapeutic agents in vitro and in vivo. Mol Cancer Ther 10(12):2340-2349. https ://doi.org/10.1158/1535-7163.Mct-11-0415

144. Shoemaker AR, Mitten MJ, Adickes J, Ackler S, Refici M, Ferguson D, Oleksijew A, O'Connor JM, Wang B, Frost DJ, Bauch J, Marsh K, Tahir SK, Yang X, Tse C, Fesik SW, Rosenberg SH, Elmore SW (2008) Activity of the Bcl-2 family inhibitor ABT263 in a panel of small cell lung cancer xenograft models. Clin Cancer Res 14(11):3268-3277. https://doi.org/10.1158/10780432.Ccr-07-4622

145. Schoenwaelder SM, Jarman KE, Gardiner EE, Hua M, Qiao J, White MJ, Josefsson EC, Alwis I, Ono A, Willcox A, Andrews RK, Mason KD, Salem HH, Huang DC, Kile BT, Roberts AW, Jackson SP (2011) Bcl-xL-inhibitory BH3 mimetics can induce a transient thrombocytopathy that undermines the hemostatic function of platelets. Blood 118(6):1663-1674. https://doi. org/10.1182/blood-2011-04-347849

146. Mason KD, Carpinelli MR, Fletcher JI, Collinge JE, Hilton AA, Ellis S, Kelly PN, Ekert PG, Metcalf D, Roberts AW, Huang DC, Kile BT (2007) Programmed anuclear cell death delimits platelet life span. Cell 128(6):1173-1186. https://doi.org/10.1016/j. cell.2007.01.037

147. Bai L, Chen J, Liu L, McEachern D, Aguilar A, Zhou H, Yang CY, Wang H, Wen J, Wang G, Zhai Y, Guo M, Yang D, Wang S (2014) 338 BM-1252 (APG-1252): a potent dual specific Bcl-2/ $\mathrm{Bcl}-\mathrm{xL}$ inhibitor that achieves complete tumor regression with minimal platelet toxicity. Eur J Cancer 50:109-110. https://doi. org/10.1016/S0959-8049(14)70464-2

148. Lakhani NJ, Rasco DW, Tolcher AW, Huang Y, Ji J, Wang H, Dong Q, Men L, O'Rourke TJ, Chandana SR, Amaya A, Cole Y, Kaiser B, Mays TA, Patnaik A, Papadopoulos KP, Yang D, Zhai Y (2018) A phase I study of novel dual Bcl-2/Bcl-xL inhibitor APG-1252 in patients with advanced small cell lung cancer (SCLC) or other solid tumor. J Clin Oncol 36(15_suppl):25942594. https://doi.org/10.1200/JCO.2018.36.15_suppl.2594

149. Souers AJ, Leverson JD, Boghaert ER, Ackler SL, Catron ND, Chen J, Dayton BD, Ding H, Enschede SH, Fairbrother WJ, Huang DC, Hymowitz SG, Jin S, Khaw SL, Kovar PJ, Lam LT, Lee J, Maecker HL, Marsh KC, Mason KD, Mitten MJ, Nimmer PM, Oleksijew A, Park CH, Park CM, Phillips DC, Roberts AW, Sampath D, Seymour JF, Smith ML, Sullivan GM, Tahir SK, Tse C, Wendt MD, Xiao Y, Xue JC, Zhang H, Humerickhouse RA, Rosenberg SH, Elmore SW (2013) ABT-199, a potent and selective BCL-2 inhibitor, achieves antitumor activity while sparing platelets. Nat Med 19(2):202-208. https://doi.org/10.1038/ nm.3048 
150. Valentin R, Grabow S, Davids MS (2018) The rise of apoptosis: targeting apoptosis in hematologic malignancies. Blood 132(12):1248-1264. https://doi.org/10.1182/blood-2018-02791350

151. Amundson SA, Myers TG, Scudiero D, Kitada S, Reed JC, Fornace AJ Jr (2000) An informatics approach identifying markers of chemosensitivity in human cancer cell lines. Cancer Res 60(21):6101-6110

152. Lessene G, Czabotar PE, Sleebs BE, Zobel K, Lowes KN, Adams JM, Baell JB, Colman PM, Deshayes K, Fairbrother WJ, Flygare JA, Gibbons P, Kersten WJ, Kulasegaram S, Moss RM, Parisot JP, Smith BJ, Street IP, Yang H, Huang DC, Watson KG (2013) Structure-guided design of a selective BCL-X(L) inhibitor. Nat Chem Biol 9(6):390-397. https://doi.org/10.1038/nchem bio. 1246

153. Koehler MF, Bergeron P, Choo EF, Lau K, Ndubaku C, Dudley D, Gibbons P, Sleebs BE, Rye CS, Nikolakopoulos G, Bui C, Kulasegaram S, Kersten WJ, Smith BJ, Czabotar PE, Colman PM, Huang DC, Baell JB, Watson KG, Hasvold L, Tao ZF, Wang L, Souers AJ, Elmore SW, Flygare JA, Fairbrother WJ, Lessene G (2014) Structure-guided rescaffolding of selective antagonists of BCL-XL. ACS Med Chem Lett 5(6):662-667. https://doi.org/10.1021/ml500030p

154. Tao ZF, Hasvold L, Wang L, Wang X, Petros AM, Park CH, Boghaert ER, Catron ND, Chen J, Colman PM, Czabotar PE, Deshayes K, Fairbrother WJ, Flygare JA, Hymowitz SG, Jin S, Judge RA, Koehler MF, Kovar PJ, Lessene G, Mitten MJ, Ndubaku CO, Nimmer P, Purkey HE, Oleksijew A, Phillips DC, Sleebs BE, Smith BJ, Smith ML, Tahir SK, Watson KG, Xiao Y, Xue J, Zhang H, Zobel K, Rosenberg SH, Tse C, Leverson JD, Elmore SW, Souers AJ (2014) Discovery of a potent and selective BCL-XL inhibitor with in vivo activity. ACS Med Chem Lett 5(10):1088-1093. https://doi. org $/ 10.1021 / \mathrm{ml} 5001867$

155. Leverson JD, Phillips DC, Mitten MJ, Boghaert ER, Diaz D, Tahir SK, Belmont LD, Nimmer P, Xiao Y, Ma XM, Lowes KN, Kovar P, Chen J, Jin S, Smith M, Xue J, Zhang H, Oleksijew A, Magoc TJ, Vaidya KS, Albert DH, Tarrant JM, La N, Wang L, Tao ZF, Wendt MD, Sampath D, Rosenberg SH, Tse C, Huang DC, Fairbrother WJ, Elmore SW, Souers AJ (2015) Exploiting selective BCL-2 family inhibitors to dissect cell survival dependencies and define improved strategies for cancer therapy. Sci Transl Med 7(279):279ra240. https://doi. org/10.1126/scitranslmed.aaa4642

156. van Delft MF, Wei AH, Mason KD, Vandenberg CJ, Chen L, Czabotar PE, Willis SN, Scott CL, Day CL, Cory S, Adams JM, Roberts AW, Huang DC (2006) The BH3 mimetic ABT737 targets selective $\mathrm{Bcl}-2$ proteins and efficiently induces apoptosis via Bak/Bax if Mcl-1 is neutralized. Cancer Cell 10(5):389-399. https://doi.org/10.1016/j.ccr.2006.08.027

157. Williams MM, Lee L, Hicks DJ, Joly MM, Elion D, Rahman B, McKernan C, Sanchez V, Balko JM, Stricker T, Estrada MV, Cook RS (2017) Key survival factor, Mcl-1, correlates with sensitivity to combined Bcl-2/Bcl-xL blockade. Mol Cancer Res 15(3):259-268. https://doi.org/10.1158/1541-7786. Mcr-16-0280-t

158. Akagi $\mathrm{H}$, Higuchi $\mathrm{H}$, Sumimoto $\mathrm{H}$, Igarashi $\mathrm{T}$, Kabashima A, Mizuguchi H, Izumiya M, Sakai G, Adachi M, Funakoshi S, Nakamura S, Hamamoto Y, Kanai T, Takaishi H, Kawakami Y, Hibi T (2013) Suppression of myeloid cell leukemia-1 (Mcl-1) enhances chemotherapy-associated apoptosis in gastric cancer cells. Gastric Cancer 16(1):100-110. https://doi.org/10.1007/ s10120-012-0153-6

159. Wertz IE, Kusam S, Lam C, Okamoto T, Sandoval W, Anderson DJ, Helgason E, Ernst JA, Eby M, Liu J, Belmont LD, Kaminker JS, O’Rourke KM, Pujara K, Kohli PB, Johnson AR,
Chiu ML, Lill JR, Jackson PK, Fairbrother WJ, Seshagiri S, Ludlam MJ, Leong KG, Dueber EC, Maecker H, Huang DC, Dixit VM (2011) Sensitivity to antitubulin chemotherapeutics is regulated by MCL1 and FBW7. Nature 471(7336):110-114. https://doi.org/10.1038/nature09779

160. Hird AW, Tron AE (2019) Recent advances in the development of Mcl-1 inhibitors for cancer therapy. Pharmacol Ther 198:59-67. https://doi.org/10.1016/j.pharmthera.2019.02.007

161. Abulwerdi F, Liao C, Liu M, Azmi AS, Aboukameel A, Mady AS, Gulappa T, Cierpicki T, Owens S, Zhang T, Sun D, Stuckey JA, Mohammad RM, Nikolovska-Coleska Z (2014) A novel small-molecule inhibitor of mcl-1 blocks pancreatic cancer growth in vitro and in vivo. Mol Cancer Ther 13(3):565575. https://doi.org/10.1158/1535-7163.Mct-12-0767

162. Leverson JD, Zhang H, Chen J, Tahir SK, Phillips DC, Xue J, Nimmer P, Jin S, Smith M, Xiao Y, Kovar P, Tanaka A, Bruncko M, Sheppard GS, Wang L, Gierke S, Kategaya L, Anderson DJ, Wong C, Eastham-Anderson J, Ludlam MJ, Sampath D, Fairbrother WJ, Wertz I, Rosenberg SH, Tse C, Elmore SW, Souers AJ (2015) Potent and selective small-molecule MCL-1 inhibitors demonstrate on-target cancer cell killing activity as single agents and in combination with ABT-263 (navitoclax). Cell Death Dis 6:e1590. https://doi.org/10.1038/ cddis.2014.561

163. Caenepeel S, Brown SP, Belmontes B, Moody G, Keegan KS, Chui D, Whittington DA, Huang X, Poppe L, Cheng AC, Cardozo M, Houze J, Li Y, Lucas B, Paras NA, Wang X, Taygerly JP, Vimolratana M, Zancanella M, Zhu L, Cajulis E, Osgood T, Sun J, Damon L, Egan RK, Greninger P, McClanaghan JD, Gong J, Moujalled D, Pomilio G, Beltran P, Benes CH, Roberts AW, Huang DC, Wei A, Canon J, Coxon A, Hughes PE (2018) AMG 176, a selective MCL1 inhibitor, is effective in hematologic cancer models alone and in combination with established therapies. Cancer Discov 8(12):1582-1597. https ://doi.org/10.1158/2159-8290.Cd-18-0387

164. Tron AE, Belmonte MA, Adam A, Aquila BM, Boise LH, Chiarparin E, Cidado J, Embrey KJ, Gangl E, Gibbons FD, Gregory GP, Hargreaves D, Hendricks JA, Johannes JW, Johnstone RW, Kazmirski SL, Kettle JG, Lamb ML, Matulis SM, Nooka AK, Packer MJ, Peng B, Rawlins PB, Robbins DW, Schuller AG, Su N, Yang W, Ye Q, Zheng X, Secrist JP, Clark EA, Wilson DM, Fawell SE, Hird AW (2018) Discovery of Mcl-1-specific inhibitor AZD5991 and preclinical activity in multiple myeloma and acute myeloid leukemia. Nat Commun 9(1):5341. https://doi.org/10.1038/s41467-018-07551-w

165. Kotschy A, Szlavik Z, Murray J, Davidson J, Maragno AL, Le Toumelin-Braizat G, Chanrion M, Kelly GL, Gong JN, Moujalled DM, Bruno A, Csekei M, Paczal A, Szabo ZB, Sipos S, Radics G, Proszenyak A, Balint B, Ondi L, Blasko G, Robertson A, Surgenor A, Dokurno P, Chen I, Matassova N, Smith J, Pedder C, Graham C, Studeny A, Lysiak-Auvity G, Girard AM, Grave F, Segal D, Riffkin CD, Pomilio G, Galbraith LC, Aubrey BJ, Brennan MS, Herold MJ, Chang C, Guasconi G, Cauquil N, Melchiore F, Guigal-Stephan N, Lockhart B, Colland F, Hickman JA, Roberts AW, Huang DC, Wei AH, Strasser A, Lessene G, Geneste O (2016) The MCL1 inhibitor S63845 is tolerable and effective in diverse cancer models. Nature 538(7626):477-482. https://doi.org/10.1038/ nature 19830

166. Soderquist RS, Crawford L, Liu E, Lu M, Agarwal A, Anderson GR, Lin KH, Winter PS, Cakir M, Wood KC (2018) Systematic mapping of BCL-2 gene dependencies in cancer reveals molecular determinants of BH3 mimetic sensitivity. Nat Commun 9(1):3513. https://doi.org/10.1038/s41467-018-05815-z

167. Huang S, Sinicrope FA (2010) Celecoxib-induced apoptosis is enhanced by ABT-737 and by inhibition of autophagy in 
human colorectal cancer cells. Autophagy 6(2):256-269. https ://doi.org/10.4161/auto.6.2.11124

168. Raats DA, de Bruijn MT, Steller EJ, Emmink BL, Borel-Rinkes IH, Kranenburg O (2011) Synergistic killing of colorectal cancer cells by oxaliplatin and ABT-737. Cell Oncol (Dordr) 34(4):307-313. https://doi.org/10.1007/s13402-011-0026-8

169. Okumura K, Huang S, Sinicrope FA (2008) Induction of Noxa sensitizes human colorectal cancer cells expressing Mcl-1 to the small-molecule Bcl-2/Bcl-xL inhibitor, ABT-737. Clin Cancer Res 14(24):8132-8142. https://doi.org/10.1158/10780432.Ccr-08-1665

170. Berger S, Procko E, Margineantu D, Lee EF, Shen BW, Zelter A, Silva DA, Chawla K, Herold MJ, Garnier JM, Johnson R, MacCoss MJ, Lessene G, Davis TN, Stayton PS, Stoddard BL, Fairlie WD, Hockenbery DM, Baker D (2016) Computationally designed high specificity inhibitors delineate the roles of BCL2 family proteins in cancer. eLife. https://doi.org/10.7554/eLife .20352

171. Greaves G, Milani M, Butterworth M, Carter RJ, Byrne DP, Eyers PA, Luo X, Cohen GM, Varadarajan S (2019) BH3only proteins are dispensable for apoptosis induced by pharmacological inhibition of both MCL-1 and BCL-XL. Cell Death Differ 26(6):1037-1047. https://doi.org/10.1038/s4141 8-018-0183-7

Publisher's Note Springer Nature remains neutral with regard to jurisdictional claims in published maps and institutional affiliations. 